\title{
Why Do Some Vertebrates Have Microchromosomes?
}

\author{
Kornsorn Srikulnath 1,2,3,4,5,*(D), Syed Farhan Ahmad 1,2,3,4, Worapong Singchat ${ }^{1,2,4}$ and Thitipong Panthum ${ }^{1,2,4}$ \\ 1 Animal Genomics and Bioresource Research Center (AGB Research Center), Faculty of Science, \\ Kasetsart University, 50 Ngamwongwan, Chatuchak, Bangkok 10900, Thailand; \\ farhan.phd.unesp@gmail.com (S.F.A.); worapong.si@ku.th (W.S.); thitipong.pa@ku.th (T.P.) \\ 2 Laboratory of Animal Cytogenetics and Comparative Genomics (ACCG), Department of Genetics, \\ Faculty of Science, Kasetsart University, 50 Ngamwongwan, Chatuchak, Bangkok 10900, Thailand \\ 3 The International Undergraduate Program in Bioscience and Technology, Faculty of Science, \\ Kasetsart University, 50 Ngamwongwan, Chatuchak, Bangkok 10900, Thailand \\ 4 Special Research Unit for Wildlife Genomics (SRUWG), Department of Forest Biology, Faculty of Forestry, \\ Kasetsart University, 50 Ngamwongwan, Chatuchak, Bangkok 10900, Thailand \\ 5 Amphibian Research Center, Hiroshima University, 1-3-1, Kagamiyama, Higashihiroshima 739-8526, Japan \\ * Correspondence: kornsorn.s@ku.ac.th
}

check for updates

Citation: Srikulnath, K.; Ahmad, S.F.; Singchat, W.; Panthum, T. Why Do Some Vertebrates Have

Microchromosomes? Cells 2021, 10, 2182. https://doi.org/10.3390/cells 10092182

Academic Editor: Laura Fanti

Received: 22 June 2021

Accepted: 17 August 2021

Published: 24 August 2021

Publisher's Note: MDPI stays neutral with regard to jurisdictional claims in published maps and institutional affiliations.

Copyright: (c) 2021 by the authors. Licensee MDPI, Basel, Switzerland. This article is an open access article distributed under the terms and conditions of the Creative Commons Attribution (CC BY) license (https:/ / creativecommons.org/licenses/by/ $4.0 /)$.
Abstract: With more than 70,000 living species, vertebrates have a huge impact on the field of biology and research, including karyotype evolution. One prominent aspect of many vertebrate karyotypes is the enigmatic occurrence of tiny and often cytogenetically indistinguishable microchromosomes, which possess distinctive features compared to macrochromosomes. Why certain vertebrate species carry these microchromosomes in some lineages while others do not, and how they evolve remain open questions. New studies have shown that microchromosomes exhibit certain unique characteristics of genome structure and organization, such as high gene densities, low heterochromatin levels, and high rates of recombination. Our review focuses on recent concepts to expand current knowledge on the dynamic nature of karyotype evolution in vertebrates, raising important questions regarding the evolutionary origins and ramifications of microchromosomes. We introduce the basic karyotypic features to clarify the size, shape, and morphology of macro- and microchromosomes and report their distribution across different lineages. Finally, we characterize the mechanisms of different evolutionary forces underlying the origin and evolution of microchromosomes.

Keywords: evolution; karyotype; chromosomal rearrangements; genes; genome

\section{Introduction}

The year 2020 was the bicentennial of Charles Darwin's birth and the 150th anniversary of the publication of his well-known book, "On the Origin of Species by Means of Natural Selection". One section is entitled, "Organs of extreme perfection and complication" [1], which describes the main features of eye evolution, their prominent position in the body, and their role in developmental and evolutionary biology. Darwin hypothesizes that both a primitive and a complex eye may be evolved from rhodopsin, an ancient molecule, and further explains the effect of eyes on the diversification of life-forms, and the interaction between genetics and developmental biology [1]. Importantly, rhodopsin is found throughout the domain of eukaryotes and is also present in prokaryotes. The rhodopsin family of molecules serves as the photosensitive chemical in all vision systems in creatures across the evolutionary tree, and has been conserved for more than a billion years of life [2-4]. The exact nucleotide and amino acid sequences may differ, and the photochemical cascade differs in its details; however, the basic vitamin A aldehyde-protein pairing is still a stable feature. Rhodopsin is also ubiquitous in multicellular animals [5], thus reflecting a basic unification of life-forms in a similar way to genetic material such as chromosomes. 
Chromosomes are thread-like structures located inside the nucleus of eukaryotic organisms. Each chromosome comprises DNA moleculaes coiled around proteins, with specific instructions that make each type of living creature unique and is passed equally from parents to offspring. Chromosomes are normally visible under a light microscope only when the cell is undergoing the metaphase of cell division, where all chromosomes are in their highly condensed form, comprising short and long arms and centromeric constriction. Notwithstanding this, in specific lineages of vertebrates, the chromosome set is bimodally characterized by great variations in size and commonly termed as microand macrochromosomes, although there is not always a sharp borderline between the two groups (Figure 1). Microchromosomes are a type of smaller chromosome and typical components of avian karyotypes [6]. They have also been observed in some reptilians such as snakes, lizards, and turtles [7-9], and in other vertebrates including amphibians $[10,11]$ and fish [12], but they are not found in mammals. Microchromosomes behave like any other chromosomes; they are stably maintained during cell division and have functional centromeres and telomeres [13]. Microchromosomes are also found in insects, particularly in the Belostomatidae family [14-18].

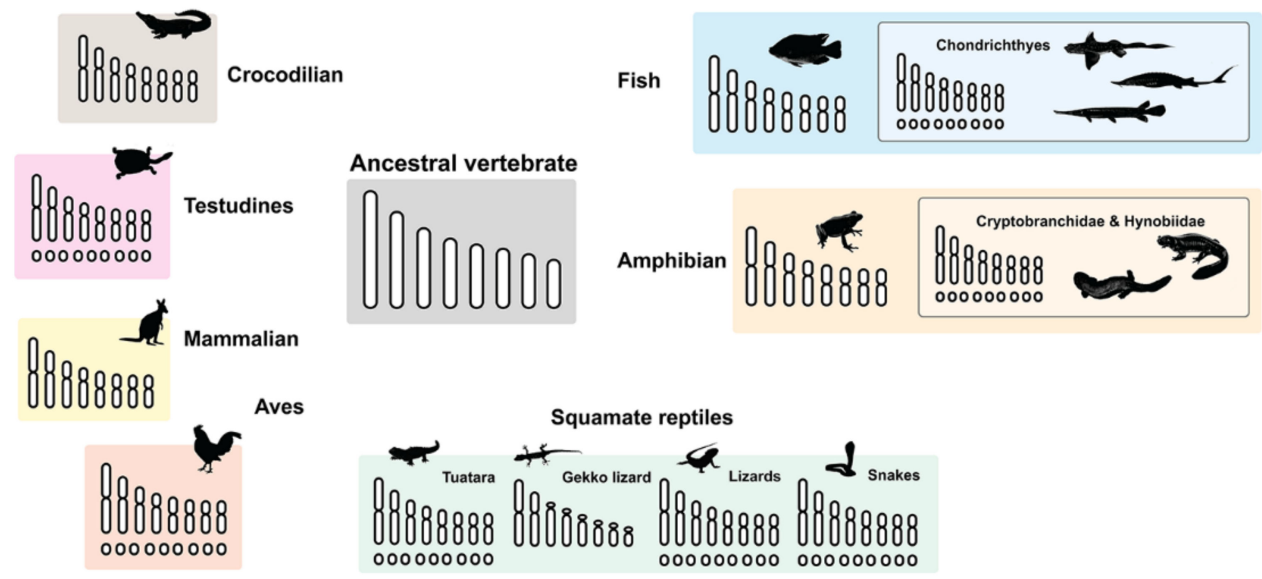

Figure 1. Microchromosome distribution of vertebrates and karyotypic ideograms.

The physical and genetic maps of chickens are the most developed with important international efforts also underway to build a complete genome map similar to what has been done for humans [19-21]. Microchromosomes were originally discovered in chicken chromosome preparations, leading to the adoption of the chicken chromosome as the model reference genome, with chromosome size difference and evolutionary linkage homology in vertebrates [22-25]. Most chicken microchromosomes belong to ancestral linkage groups, resulting in hypothetical ancestral microchromosomes of vertebrates $[9,26,27]$. The recent emergence of genomics has offered in-depth insights to trace the evolutionary history and unlock the chromosome level mechanisms that might have reshaped ancestral vertebrate evolution [28]. A marine chordate was found to have two successive whole genome duplications (WGD) 450 million years ago (Mya) before becoming the common ancestor of vertebrates and diversifying into the more than 70,000 species found today $[27,29,30]$. The separation of Agnatha (jawless fish) as the primitive vertebrates and Gnathostomata (jawed fish) was found to have four more fusions to form the ancestral Euteleostomi (bony vertebrates) genome of 50 chromosomes [27]. A first version of the ancestral vertebrate pre-2R WGD (2nd round of WGD) protochromosomes was reconstructed using duplicated regions of the human genome, containing four copies of the ancestral diploid vertebrate genome $[29,31]$. The scenario probably starts from $10-13$ protochromosomes, each duplicating twice into 40 chromosomes during the $2 \mathrm{R}-\mathrm{WGD}$, but including three repeated fissions and the loss of six chromosomes. The comparison of the lancelet (amphioxus) genome (Branchiostoma floridae, Hubbs, 1922) [32] with the genome of several vertebrates defined the unordered gene content of 17 ancestral chordate linkage groups of the last common 
chordate ancestor, which revealed a global four-fold conserved linkage homology with vertebrate genomes $[33,34]$. Surprisingly, when gar and chicken genomes were compared, almost half of the gar karyotype (14/29 chromosomes) showed a one to one relationship with chicken chromosomes, including microchromosomes [27,35]. Thus, microchromosomes may be ancestral features in Euteleostomes, which in turn raises a scenario for their origin through $2 \mathrm{R}$ duplications. However, in this setting, chromosome evolution would tend to favor fusions into fewer and larger chromosomes, as found in mammals [36]. Therefore, "How can we predict evolutionary direction and the crucial impact of microchromosomes?" Returning to the rhodopsin story, Darwin states, "It would be best to trace the gradual development of complex eyes in the ancestors of presently known animals. Since the fossil record does not allow this, we should look to the entire spectrum of eyes in various extant species. We can emphasize that these changes, although happening gradually through the immensity of geological time, could occur by the power of natural selection" $[37,38]$. However, evolution could change one part of an organism without interfering with the integrity and survivability of the organism as a whole. A similar idea is now applied by current evolutionary biologists for microchromosomal implications and origins.

In light of this whole scenario, the critically intriguing question is why such a high proportion of small chromosomes have persisted in specific lineages. Is it possible that the existence of many small chromosomes represents a specialized system for information storing? Taking advantage of data sourced from the recently achieved milestone of comparative genomics of several vertebrate genomes, we review the evidence pertaining to the origin and different genetic profiles between macro- and microchromosomes in vertebrates. Hopefully, this evidence will help answer the main research question of why some vertebrates have macro- and microchromosomes.

\section{How Can We Clarify Karyotypic Features of Micro- and Macrochromosomes?}

It remains difficult to make definite counts of the number and morphology of microchromosomes based on reports of different vertebrate karyotypes, because no standard rules exist for the identification of macro- and microchromosomes [6,39,40]. Generally, microchromosomes, as a particular type of very small chromosomes, are morphologically indistinguishable as dots on metaphase plate chromosomes [9,39,41,42]. All microchromosomes arrange with each homologous pair, and several reports have attempted to measure the actual size of microchromosomes by scale bar or computationally as digital pixels [43-45]. However, the size of each microchromosome varies depending on the condensation state of each metaphase cell, creating difficulty to precisely organize the pattern $[46,47]$. The classical criterion to define microchromosomes is their size, which varies between research groups from 0.5 to $1.5 \mu \mathrm{m}[28,40,45,48,49]$. When crudely determining the category of chromosomes, the centromeric position of microchromosomes cannot be defined by conventional staining such as orcein or Giemsa, whereas macrochromosomes can be designated as metacentric, sub-metacentric, sub-telocentric, and acrocentric. The chicken genome contains $2 n=78$ chromosomes ranging in size between $250 \mathrm{Mb}$ (the largest macrochromosome) [50] and $3.5 \mathrm{Mb}$ (the smallest microchromosome) [6,51], and a total genome size of $1.1 \mathrm{~Gb}[20,52]$. Chicken chromosomes are classified arbitrarily into two major groups: the macrochromosomes ranging from 30 to $250 \mathrm{Mb}$ (chromosomes $1-8$ and the sex chromosomes ( $\mathrm{ZZ}$, male or $\mathrm{ZW}$, female)), whereas the remaining smaller chromosomes are microchromosomes of, on average, $12 \mathrm{Mb}$ in length (the smallest being $3.5 \mathrm{Mb}$ ) [20,51]. In addition to chicken microchromosomes, other amniote groups possess microchromosomes generally $<30 \mathrm{Mb}$ in length $[6,25,53,54]$. In reptiles, microchromosomes in snakes (such as Naja naja) can attain a small size of around $10 \mathrm{Mb}$; in turtles (such as Chelonia mydas), the smallest microchromosomes recorded were $7.8 \mathrm{Mb}$ in length; whereas in lizards (such as Lacerta agilis) the minimum microchromosomes are $12 \mathrm{Mb}$ in size (https:/ / www.ncbi.nlm.nih.gov / assembly /?term=Reptiles, accessed on 1 July 2021). 
Genome sequencing of many vertebrate species now provides unprecedented detail sufficient to compare microchromosomes across diverse lineages.

\section{Microchromosome Distribution in Vertebrate Lineage}

Large microchromosome distribution is observed across the vertebrate clade, with variable microchromosome numbers ranging from one pair of microchromosomes in various lizard species such as Bosk's Fringe-fingered lizard (Acanthodactylus spp.), lacertid (Lacerta spp.), racerunner lizard (Eremias spp.), and snake-eyed lizard (Ophisops elegans) to more than 40 pairs in Arctic lamprey (Lethenteron camtschaticum) [28,55-58] (Figure 1). The occurrence of a diversity in chromosome number between different vertebrates presents an opportunity to correlate chromosome evolution with the timing and types of events [27].

Bird karyotypes are generally composed of $\sim 80$ chromosomes. Of these, 7 or 8 pairs of the largest chromosomes are macrochromosomes ranging from 3-6 $\mu \mathrm{m}$ in length, whereas the remaining 30 to 32 pairs are microchromosomes of $0.5-2.5 \mu \mathrm{m}$ in length $[39,42,59,60]$. Apart from the Falconiformes (falcons) and the Psittaciformes (parrots), which have reduced diploid numbers with fewer microchromosomes [61], there is neither a gradual reduction nor an increase of microchromosome numbers or total length during long term evolution in birds [6].

The bimodal karyotypic feature is also observed in turtles that have chromosome numbers of $2 n=28-66$ [62-64], with a range of macrochromosomes between 10 and 36, and up to 56 microchromosomes [58] (Table 1). Despite such variability, karyotypes are presented for 13 of the 14 genera of side-necked turtles (suborder Pleurodira, families Pelomedusidae and Chelidae). Pelomedusids have low diploid numbers and few microchromosomes $(2 n=26-36)$; the five largest chromosomes are homologous in the three genera. Despite this substantial homology, some pericentromeric regions of macrochromosomes can also show interspecific chromosomal differences. For example, a comparative analysis of satellite sequences among the four sea turtle species including Chelonia mydas, Caretta caretta, Eretmochelys imbricata, and Lepidochelys olivacea showed species-specific variation of microsatellites in heterochromatin regions [65]. Chelids have a high diploid number and many microchromosomes $(2 n=50-64)$ and are similar in this respect to cryptodires $(2 n=50-66)$. The sea turtle species (Cheloniidae) showed a diploid number of 56 chromosomes, arranged in 11 bi-armed chromosome pairs (1-10 and 12) and 17 acrocentric pairs (11 and 13-28; 13-28 were microchromosomes), and $\mathrm{FN}=78$. 
Table 1. Range of genomic features in different classes of vertebrates.

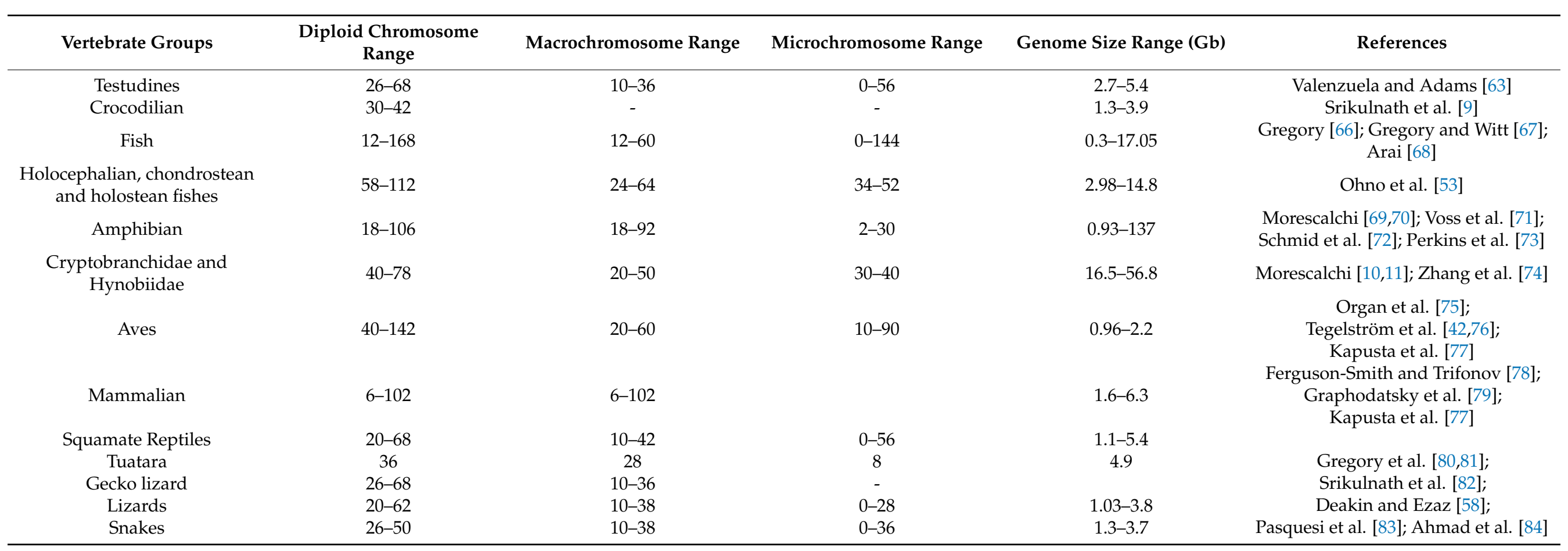


In Lepidosauromorpha (tuataras and squamate reptiles), tuataras have a diploid chromosome number of $2 n=36$, consisting of 14 pairs of macrochromosomes and 4 pairs of microchromosomes $[85,86]$, whereas squamate reptiles show substantial karyotypic variability with a diploid number of chromosomes ranging from $2 n=20-68$ [87]. This high variation is arguably driven by dynamic repeated fusion of macro- and microchromosomes. Furthermore, certain squamate reptiles may harbor very few or no dot-shaped microchromosomes, for example, in lacertid lizards (Lacertidae) and geckos (Gekkonidae) [56,58,88-100], whereas other squamates can carry as many as 36 microchromosomes [99]. The most common chromosome number in snakes is $2 n=36$, comprising 16 macrochromosomes and 20 microchromosomes, while worm lizards show a large variation in chromosome number $(2 n=30-50)[88,100]$. The extant lizards (Lacertilia) also exhibit a large variation in both chromosome number $(2 n=24-46)$ and chromosome morphology [88] (Figure 1). By contrast, the crocodile karyotype contains chromosomes with the absence of microchromosomes [9,101,102]. Considering avian and non-avian reptiles, the question arises as to why geckos and crocodiles do not contain a microchromosomal structure, despite being in the same evolutionary line.

Apart from amniotes, most fish have between 40 and 60 chromosomes, while some (holocephalian, chondrostean, holostean) showed karyotypes with microchromosomes $[53,103]$. In most fish families (Anostomidae, Prochilodontidae, Curimatidae), microchromosomes are often present as accessory elements [104], such as in Astyanax mexicanus whereby microchromosomes occur as supernumerary B chromosomes $[105,106]$. Furthermore, it is possible that microchromosomes are present in the karyotypes of many primitive vertebrates $[10,11,53,69]$. Lastly, the chromosomal frequency of freshwater fish is higher than marine fish, suggesting that karyotypic dynamics can change with species habitat [103].

Interspecies changes in karyomorphic and chromosomal frequency, with different numbers of microchromosomes, have also been observed in amphibians such as primitive species of Urodela, Anura, and Apoda [70,72]. Nevertheless, the rate of chromosomal rearrangements in amphibians was previously estimated to be less frequent compared to mammals [107]. Recent genomic studies have shown that chromosomes experienced high levels of fusion type rearrangements in salamanders and frog species $[108,109]$. Further studies are required to investigate whether this high-level tendency of chromosomal rearrangements in amphibian genomes can trigger the formation of microchromosomes, and how such forces might impact their evolution. Although the distributions of microchromosomes in some vertebrate groups are more well-studied, the advent of molecular cytogenetic, genomic, and bioinformatic approaches has offered the opportunity to test long-standing hypotheses in both model and non-model taxa.

\section{Differences in Characteristics of Macro- and Microchromosomes}

Vertebrate microchromosomes consistently exhibit many distinct features across lineages, including high gene density and high rates of recombination, thus representing a functionally and evolutionarily unique fraction of the genomes [20,52,54,110-112]. Chicken microchromosomes are GC-rich, contain CpG islands, comprise $50 \%$ of all genes derived from the level of methylation, and are 2-3 times as gene-dense as the macrochromosomes [22,39,52,113-118]. By contrast, the macrochromosomes are AT-rich and exhibit weak R-, C-, and T-banding [39,119]. Generally, the GC-content of chromosomes increases exponentially with the reduction in chromosomal size (ICGSC, 2004 [52,120,121]; however, a few exceptions are evident. For instance, this tendency is not seen in most teleosts [122], whereas primitive fish such as lamprey show a significant association between GC\% and chromosome sizes. Furthermore, amphibians, e.g., salamander and frog species (Ambystoma mexicanum, Xenopus laevis, X. tropicalis), do not show a correlation between GC $\%$ and chromosome size either [122]. This indicates that GC\% increases together with genome size in these instances, suggesting that lineages comprising several microchromosomes might be the counterparts of mammalian GC-rich chromosomal segments. Researchers [115] attempted to address this statistically by analyzing chicken chromosomes that were outliers to the "smaller chromosome size = more gene-dense" rule. Chromosome size-dependent GC heterogeneity seems to be a widespread characteristic in 
sauropsids (avian and non-avian reptiles), whose karyotypes consist of microchromosomes, and possibly originated from the common ancestor of sauropsids $[40,74,123,124]$. Previous studies demonstrated by comparative genomics that chromosomes have been highly conserved between the chicken and the turtle $[76,125,126]$. For instance, the karyotype of the Chinese soft-shelled turtle (Pelodiscus sinensis, Wiegmann, 1835) [127], which consists of 9 pairs of macrochromosomes and 24 pairs of microchromosomes $(2 n=66)$, is very similar to the chicken karyotype [128]. Furthermore, it is assumed that around 50\% of total gene contents are localized on the microchromosomes in avian genomes $[6,43,117,129]$. Chicken microchromosomes are also considered to extensively retain the ancestral linkage groups of genes [117]. Moreover, GC-poor genes are two to three times more likely to reside on macrothan on microchromosomes in both chicken and turtle genomes, whereas GC-rich genes tend to reside equally on macro- and microchromosomes [40]. Concurrently, several types of microchromosome-specific repeated sequences are reported $[128,130,131]$ in turtles and avians. Since these microchromosome-specific repeated sequences are GC-rich, it is possible that heterochromatic regions also contribute to the high GC-content in microchromosomes as well as regions where functional genes are coded. Moreover, a chromosome size-dependent GC heterogeneity was also identified in the red-eared slider turtle (Trachemys scripta elegans, Wied-Neuwied, 1839) [132] and the Nile crocodile (Crocodylus niloticus, Laurenti, 1768) [133] using a chromosome flow sorting technique [123]. The GC portion that encompasses genomic regions (over the scale of several $\mathrm{kb}$ to $\mathrm{Mb}$ ) forms the "isochore" which has been extensively reported in crocodiles and turtles [134-136]. Recently, these isochores have also been identified in teleost genomes with similar characteristics. Researchers $[135,137,138]$ analyzed the GC-content of exonic third codon positions (GC3) of more than 6000 expressed sequence tags (ESTs) in the American alligator (Alligator mississippiensis, Daudin, 1802) [139] and mentioned that the alligator genome has a certain level of GC heterogeneity suggesting the presence of GC-rich isochore in ancestors of archosaurs (birds and crocodilians). The GC content of alligator and crocodile assembled genomes was examined, and a higher average GC content was observed compared to many other vertebrates [140]. In this analysis, substantial standard deviation in GC content across assembled scaffolds suggested the presence of GC-rich isochores, indicating the heterogeneneity of the alligator genome. Snake karyotypes have also been highly conserved within this group. The usual diploid number is $2 n=36$, consisting of 8 pairs of macrochromosomes and 10 pairs of microchromosomes [95-98]. The effect of large differences of karyotypes, especially the number of microchromosomes between the snake and the other two species, might be considered. The chromosome number is largely different from the chicken karyotype because of the remarkable difference in the number of microchromosomes. This suggests that chromosomal rearrangements have occurred more frequently in the snake lineage than in chicken-turtle lineages, resulting from frequent repeated fusions between macro- and microchromosomes and between microchromosomes [82,94] (Figure 2). In total, 11 chromosomal segments homologous to chicken microchromosomes were localized to snake macrochromosomes [123]. However, snake microchromosomes contain a higher proportion of GC-rich genes than macrochromosomes, as observed in both the Chinese soft-shelled turtle and chicken $[54,123,141]$. This suggests that macrochromosomes tend to contain more GC-poor genes, whereas microchromosomes tend to contain more GC-rich genes. The correlation coefficient of GC is also lower between the rat snake (Elaphe quadrivirgata, Boie, 1826) [142] and chicken orthologs than between the Chinese softshelled turtle and chicken [123]. This might occur because the phylogenetic distance is larger between the snake and chicken than between the turtle and chicken (Figure 1). 


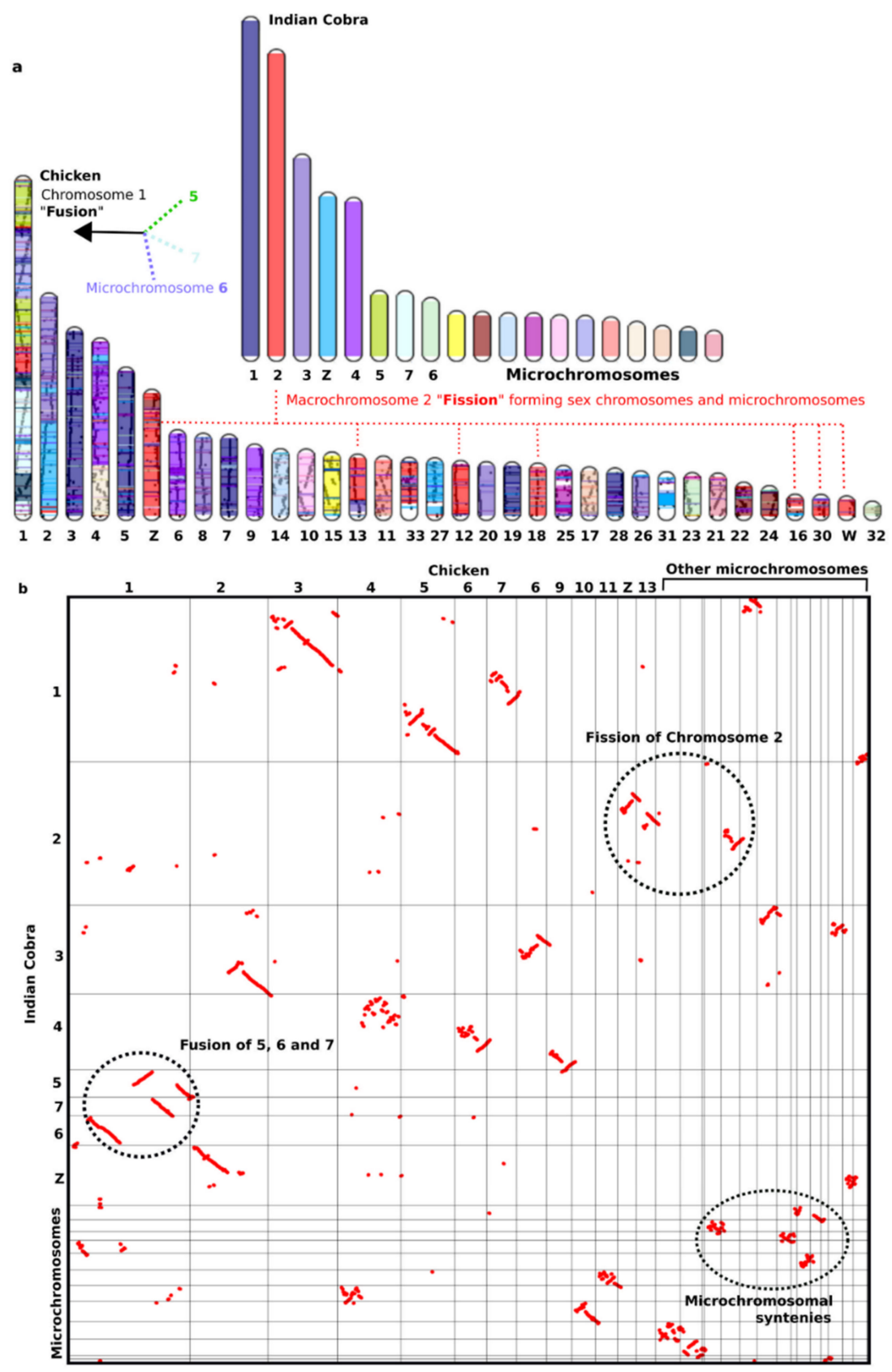

Figure 2. Cross-species homology relationship of microchromosome syntenies and inter/intrachromosomal rearrangements for the analyzed species. (a) In silico chromosome map of Indian cobra and chicken chromosomes. Same colors correspond to syntenic regions between different chromosomes. (b) A dot-plot view of genomic comparisons indicate different evolutionary patterns of chromosomal rearrangements, such as fusion, fission and microchromosomal homologies.

Chromosomal reshuffling can trigger changes in chromosome sizes and differences of GC levels, thus, causing exchange of genes between macro- and microchromosomes. This phenomenon was revealed from substantial homology between chicken microchromosomes and snakes macrochromosomes, which harbor several orthologs in both lineages. The first reptilian species for which the whole genome sequence was released was the green anole lizard (Anolis carolinensis, Voigt, 1832 [143]) [144], although with recent trends in genomics, 16 reptilian genomes have now been assembled at the chromosome level and annotated at NCBI (https:/ / www.ncbi.nlm.nih.gov/assembly /?term=reptiles, accessed on 10 May 2021). Genomic trends for other vertebrate groups are also increasing, with a total of 187 and 13 accomplished chromosome level assemblies for species of fish and 
amphibian, respectively (https: / wwww.ncbi.nlm.nih.gov/assembly/?term=reptiles, accessed on 10 May 2021). The green anole lizard, whose karyotype consists of 6 pairs of macrochromosomes and 12 pairs of microchromosomes [144,145] does not show such marked biases in GC-content between macro- and microchromosomes. Anolis has a homogeneous genome composition compared with other amniotes [144,146] and, unlike the chicken, the GC-content is similar between macro- and microchromosomes. These results make it possible to infer global GC heterogeneity of the leipidosaurian genome and the shift of GC-content caused by chromosomal rearrangements during the sauropsid evolution. Lepidosauria is a species-rich group consisting of over 10,000 extant species, and the karyotypes are also diversified within the group [56,82,84,89,90,92,93,95-98,147]. Chromosome size-dependent GC heterogeneity has probably disappeared in the specific lineage [123]. By contrast, there is no significant correlation between the GC content and the size of chromosomes that harbor them in the human and the mouse [148], consistent with analysis at the genomic level. It is still not clear whether this is a function of their small physical size or greater gene density in microchromosomes (thus, greater ability to access transcriptional machinery) [149]. Accordingly, chromosomal size-dependent GC compartmentalization seems to be unique to sauropsids, with most karyotypes consisting of macro- and microchromosomes. By contrast, chromosome sizes are relatively uniform and there is no striking bias in inter-chromosomal GC-content in most mammals. These facts indicate that sauropsids adopted chromosomal size-dependent GC compartmentalization strata, whereas mammals maintained the system in which GC-rich and -poor regions coexist on individual chromosomes in a highly juxtaposed manner. Although the intragenomic comparison of GC content across mammals, birds, and non-avian sauropsids (i.e., reptiles) revealed a similar pattern of GC heterogeneity [146], it remains unclear whether this GC heterogeneity was derived from a common ancestor or the result of a convergence that occurred independently across these lineages. This hypothesis has yet to be verified by further large-scale studies, not only in turtles, but also in other sauropsids. Several mammalian species such as shrews, microbats, tenrecs, and rabbits have experienced an increase in GC content, as marked by the identification of the most GC-poor and -rich classes of genes [148]. It is important to clarify whether monotremes, marsupials, and amphibians have a similar pattern of intra-genome GC distribution to eutherians (to speculate on the ancestral configuration for the amniote genome) by adding outgroup polarity to the present scheme. A comparison of conserved non-coding sequences (CNSs) among different vertebrates revealed that mammals tend to have highly GC-enriched flanking regions around these CNSs [84]. Further research should clarify whether the GC-enriched regions on microchromosomes are adaptive or merely the consequence of neutral evolutionary processes. Further insight into the evolution of genome structural features (such as GC regions) may spur novel studies assessing the evolutionary benefit of gene contents localized on microchromosomes.

\section{Independent Recombination Frequency between Macro- and Microchromosomes as a Driver to Change Chromosome Structure}

Recombination facilitates the successful inheritance of chromosomes during meiosis, which plays an important role in reshaping the evolutionary dynamics of organisms [150]. Comparison of the physical size of chromosomes and the rate of recombination (crossing over) reveals a strong negative relationship in birds and mammals [111]. Recombination density is higher in smaller chromosomes such as microchromosomes, resulting in an increased mean recombination rate in birds and non-avian reptiles [20,39,151]. Recombination rates are higher on microchromosomes (median rate, $6.4 \mathrm{cM} / \mathrm{Mb}$ ) than on both intermediate $(3.9 \mathrm{cM} / \mathrm{Mb})$ and macrochromosomes $(2.8 \mathrm{cM} / \mathrm{Mb})[20,110]$. The rate of recombination varies considerably between different genomic regions and is most evident between macro- and microchromosomes. The higher recombination rate on small chromosomes ensures that pairing of chromosomes occurs during meiosis [39]. This might result from the basic requirement of at least one chiasma per chromosome per meiosis, possibly facilitated by a higher density of cohesin binding sites. Cohesin can bind densely in cen- 
tromeric regions of chromosomes, where it helps mount sister chromatids onto spindle microtubules from opposing poles (biorientation), thus facilitating recombination [152]. It is believed that high densities of cohesin binding sites increase the chance of formation of the synaptonemal complex in these regions, and result in a higher rate of recombination [152-154]. Cohesin holds the sister chromatids together during the metaphase and ensures their successful segregation during cell division [155]. Moreover, meiotic recombination may tend to initiate in the accessible chromatin at gene promoters [156]. This initiation of each meiotic recombination activity occurs with the programmed formation of a DNA double-strand break (DSB), which can be repaired either as a "crossover" or as a "non-crossover" [157,158]. The domestic chicken (G. gallus) has been well studied for its highest recombination rate among birds. High frequency of recombination might be due to artificial selection during domestication, as also observed in the greylag goose (Anser anser, Linnaeus, 1758 [159]) [111,160,161]. Although earlier studies suggested an increased recombination rate in domesticates, a comprehensive later study on mammals confirmed that artificial selection does not drive the evolution of an increased recombination rate in domestic mammals. By contrast, individual bivalents of macrochromosomes had approximately the same average number of MLH1 genes (MutL homolog 1) as in the white wagtail (Motacilla alba, Linnaeus, 1758 [162]). The total numbers of crossovers in SC1-8 are 34.2 and 34.5 in the wild wagtail and the chicken [163], respectively. However, the wild wagtail microchromosomes had about one-quarter more crossovers than their chicken homologs (42.2 and 31.2, respectively). This indicates that exceptionally high recombination rates exist in the wild avian taxa. In reptiles, the comparison of the exact level of recombination at taxonomic scale is lacking, but the overall tendency of chromosomal rearrangements might suggest a high frequency of recombination [84]. It remains unexplored to which extent individual avian microchromosomes can vary in recombination rate across this lineage. Therefore, further availability of chromosome-level avian genome assemblies could unlock this information.

Similarly, recombination is closely linked to gene conversion, which has been shown to be biased toward elevating the GC content [164]. Increased GC content might have a positive effect on the expression of genes within that region, favoring the accumulation of highly expressed housekeeping genes over the larger more complex genes involved in development and transcriptional regulation [165,166]. In mammalian chromosomes, gene density differences are correlated with chromosome banding patterns as the R-bands (gene-rich) have higher gene densities than the G-bands (gene-poor) [156]. The R- and G-band regions of chromosomes are also interlinked with different aspects of nuclear organization and gene regulation [167]. Increased acetylation of the amino terminus of histone H4 is observed in transcriptionally active regions [168-170]. The distribution of acetylated $\mathrm{H} 4$ in human and hamster chromosomes has been shown to be non-random, with hyperacetylation of R-bands [171] and hypoacetylation of heterochromatic domains [172]. The avian microchromosomes also share many characteristics with these mammalian Rbands, such as high gene density, high CpG island content, and early replication in the $S$ phase $[113,116])$. Microchromosomes are hyperacetylated and most replicate early in the $S$ phase, typical characteristics of gene-rich chromosomal domains $[114,116]$. To find an indication of genes-rich domains on microchromosomes, histone acetylation studies provide a method for visualizing regions of high gene content of the genome that is independent of sequence characteristics $[173,174]$. Furthermore, preferential staining of microchromosomes with antibodies against acetylated $\mathrm{H} 4$ also provides strong evidence for elevated gene density. As previously observed, microchromosomal H4 is acetylated at multiple lysine residues [116]. This correlation between higher recombination rate/gene conversion and higher gene density suggests an evolutionary pressure for an increase in gene density on microchromosomes.

Studies in mammals report a positive correlation between GC content with both the substitution rate [175-178] and levels of genetic variation [179]. It is likely that the increased prevalence of hypermutable CpG dinucleotides in GC-rich sequences is an important fac- 
tor in increasing mutation rates in these regions [180]. A further potential correlate of substitution rate is the local recombination rate [181-184], which can be highly variable even at small scales on human chromosomes [185]. This could be due to a direct causal effect, resulting from the erroneous repair of double-strand breaks that initiate recombination [186]. However, local recombination rates also correlate with GC content [187], an observation argued to result from recombination driving the evolution of GC content [188]. Notably, many genomic features that differ between macro- and microchromosomes have been implicated to cause mutation rate variation [165,182,189-196]. When comparing microchromosomes with macrochromosomes, the results indicated $18 \%$ higher average sequence divergence in introns and $26 \%$ higher average rate of synonymous substitutions in coding sequences. In general, selective constraint is expected to homogenize differences caused by mutation rate variation. Although the presence of extended splice-sites and potential regulatory elements means that intron sequences could be subject to evolutionary constraint, selective constraint is unlikely to result in differences between intronic rates on macro- and microchromosomes. Moreover, as introns on microchromosomes tend to be shorter [20,52], a greater proportion of sequence is likely to be comprised of regulatory elements, which would result in a reduction in substitution rates on microchromosomes.

Mutations in $\mathrm{CpG}$ dinucleotides are an important factor for explaining the high divergence of microchromosomal intron sequences. Methylated $\mathrm{CpG}$ sites easily deaminate, resulting in $C \rightarrow T$ transitions possibly 10 times more frequent than other mutations [197]. A number of further effects could result in differences in substitution rates between avian autosomes, including recombination being mutagenic. Base composition may directly alter regional substitution rates if global rates of $A T \rightarrow G C$ and GC $\rightarrow$ AT mutations differ, although the effect is largely dependent on the GC content equilibrium that a sequence is evolving toward [198]. Reptilian genomes such as turtles were reported to have lower substitution mutation rates compared to mammals and birds [199-201]. This also provides them with a gene-dense structure consisting of microchromosomes with three to four times shorter intergenic sequences than on macrochromosomes. Furthermore, intergenic distances as well as the average size of the introns on microchromosomes are lower, resulting in a much higher gene density compared with macrochromosomes $[8,25]$. Indeed, these findings resurrect the question of whether the rate of recombination is generally higher in birds compared to other vertebrates [20,52], due to a higher proportion of microchromosomes and the relatively small size of avian genomes. A recent population genomics survey has identified a strong heterogeneity in recombination rates along the green anole genome [202]. Moreover, the latest findings provided evidence that macrochromosomes of vertebrates including snakes feature a high recombination rate [112]. Examining the recombination landscape in rattlesnakes using population genomic data identified rapidly evolving hotspots with activity of PRDM9 that can direct meiotic recombination. A general caveat in studies of recombination and genomic parameters is that while estimates of recombination rates reflect the contemporary situation, most genomic parameters (substitution rates, GC composition, and microchromosomal organization) are the result of long-term evolutionary processes.

\section{Nuclear Organization of Macro- and Microchromosomes}

Based on the visual inspection of fibroblast and neuronal nuclei of chickens, macrochromosome territories were located mostly toward the nuclear periphery, while microchromosome territories formed a few distinct clusters located toward the nuclear center, leading to the radial arrangements of macro- and microchromosomes [43]. In chickens, microchromosomes appear to cluster in a central position in the interphase nucleus, with the macrochromosomes occupying the nuclear periphery $[43,124,203]$. This localization correlates with the state of recombination frequency on chromosomes. Such reports have shown that most vertebrates exhibit a reduced recombination rate in chromosome centers relative to chromosome peripheries of nuclear architecture [204,205]. Low recombination frequency was observed in the telomeric regions of examined animals including ray-finned fish 
(Actinopterygii), birds, insects, and mammals [205]. The crossover rate was significantly lower in the center of chromosomes relative to their telomeric peripheries. The preferential position of mid-late replicating chromatin is at the nuclear periphery and the central position of early replicating chromatin, also previously observed in mammalian cell nuclei $[206,207]$. The reduction of recombination rates in macrochromosome centers of the zebra finch (Taeniopygia guttata, Vieillot, 1817) [208] is more extreme than in other birds [111,209], while the white wagtail macrochromosomes exhibited a clear U-shaped distribution of recombination frequencies, adding another example of comparatively reduced recombination in the centers of nuclear architecture [210]. By contrast, neighborhoods between non-homologous as well as homologous macrochromosome territories (side-by-side arrangements) are variable [43]. Epigenetic mechanisms, including DNA-methylation and histone acetylation, play an apparent role in higher-order chromatin architecture and gene expression [211,212]; however, their potential contribution to the intranuclear arrangements of chromosome territories has not been studied. In contrast to early replicating gene-dense chromatin, gene-poor mid-to-late replicating chromatin may carry binding sites for the reconstituting nuclear lamina during telophase [213]. This could push early replicating gene-dense chromatin into a more interior position, also observed in mammalian cell nuclei $[207,214]$. Furthermore, late-replicating chromatin has been observed around the nucleoli. Microchromosomes are predominantly early replicating with a small proportion of late-replicating segments $[116,119,215]$. A specific radial chromatin arrangement exists with preferential positioning of gene-dense early replicating chromatin in the nuclear interior and gene-poor late replicating chromatin at the nuclear periphery, which seems to be an evolutionarily conserved motif for the organization of the nucleus in both chicken and human cells.

Nevertheless, the stable genome organization of macro- and microchromosomes is highly conserved, with each ancestral microchromosome preferentially locating in the center at interphase $[40,43]$. Remarkably, these microchromosomes still maintain their central position in the nucleus even when recently fused to a larger chromosome (as in falcons and parrots) $[43,124,216]$. Furthermore, chromosomal arrangements noted in mitotic cells correlate to some extent with chromosome territory arrangements in interphase nuclei. However, microchromosomes may lack the necessary motifs to bind lamin proteins no matter what the karyotypic configuration [28]. It is possible, therefore, that these motifs subsequently accumulate on fused microchromosomes. Nonetheless, we would expect pressures against this: the internal gene-dense microchromosomes could provide access to transcription factories and safely keep genes away from the silencing environment of peripheral heterochromatin $[217,218]$. It is also possible, although unlikely, that the macrochromosomes lose their lamin attachments. Modeling chromatin dynamics suggests that the entire nuclear organization can invert when this tethering is interrupted [219]. Some chromatin must remain tethered to the nuclear periphery, implying that the macrochromosomal sequence will also be conserved. Recent comparative genomic analysis of $\mathrm{Hi}-\mathrm{C}$ sequencing data from multiple vertebrate lineages has shown that microchromosomes can exhibit significant levels of interchromosomal interactions and seem to be colocalized within the central nuclear territory [40]. Similar patterns of high level interchromosomal interactions for microchromosomes were also observed in chicken [220] and rattlesnake [54] genomes, and our expanded sampling indicates that these patterns are likely remarkably consistent across diverse vertebrate lineages. This analysis further suggests that microchromosomes might harbor a higher proportion of open chromatin than macrochromosomes. This model of nuclear organization represents a genomic configuration that has existed since early vertebrate evolution. Cytological observations have shown that microchromosomes in all lineages are spatially separated into a central compartment at interphase and during mitosis and meiosis. This reflects higher interaction between microchromosomes than macrochromosomes, as observed by chromosome conformation capture, and suggests some functional coherence. In highly rearranged genomes, fused microchromosomes retain 
the most ancestral characteristics but these may erode over evolutionary time. Surprisingly, de novo microchromosomes have rapidly adopted high interaction.

\section{Distribution of Repeated Sequences between Macro- and Microchromosomes}

Repeated sequences are a major source of homologous sites in chromosomal rearrangements between and within chromosomes [81,221-225]. Repeated sequences are mainly classified into tandem repeats such as satellite DNA (satDNA), mini-satDNA, and micro-satDNA [225-227], with interspersed repeats as transposable elements (TEs) [228]. A popular formation of repeated sequences is telomeric repeats, in which microchromosomes might have gained telomeric repeats preferentially as observed from the high intensity of telomeric sites on microchromosomes in birds [229]. Similar cases are also observed in several squamate reptiles [91]. This occurrence of telomeric repeats is generally rare in the macrochromosomes of turtles, but FISH mapping showed brighter signals on microchromosomes, indicating high abundance [230]. The rate of recombination might be associated with repeats such as telomeric repeats. Some regions may be functions of the initial copy number and the rate of recombination [231]. Molecular cytogenetic studies on meiotic chromosomes of the Armenian hamster suggested that interstitial (TTAGGG)n signals coincided with chiasmata, the sites of meiotic exchange [232]. The ability of telomeric sequences to promote recombination was also shown in yeast [233]. The enrichment of avian microchromosomes with (TTAGGG) $n$ repeats provides additional evidence for telomere-associated recombination. In birds, microchromosomes always show a higher rate of recombination than macrochromosomes $[6,111,151]$. This might imply that microchromosomes of squamate reptiles also present with a higher frequency of recombination than macrochromosomes. It is tempting to consider the unusually frequent occurrence of (TTAGGG) $)_{n}$ sequences as an important element in explaining the high recombination rate in species comprising microchromosomes such as birds and squamate reptiles. Unexpectedly, in the $\mathrm{W}$ sex chromosome of the lacertid lizard, (TTAGGG) $n$ sequences are abundant on microchromosomes comprising the entire chromosome [234]. This might relate to the process of sex chromosome differentiation [235-237]. Both the almost complete coverage of some microchromosomes with telomeric repeats and the presence of large telomeric arrays at one chromosomal end in another subset of microchromosomes may be caused by the amplification of (TTAGGG) $n$ repeats on these tiny chromosomes.

SatDNA repeats are fast-evolving sequences which can constitute highly repeated and/or highly conserved monomers in eukaryotic genomes ranging from 150-400 bp in length $[225,238]$. However, satellite diversity and abundance are difficult to identify because of repeat complex structures [239]. Due to reduced genome size, avian genomes are characterized by considerably lower percentages of repeats compared to other vertebrates [240]. In different species of birds such as Colaptes melanochloros (Gmelin, 1788 [241]) $(2 n=84)$ and Colaptes campestris (Vieillot, 1818 [242]), SatDNA repeats are accumulated with centromeric and telomeric regions in both macro- and microchromosomes along with clusters of $18 \mathrm{~S}$ rDNA [243]. In the Chinese soft-shelled turtle (Pelodiscus sinensis, Wiegmann, 1835 [127], family Trionychidae), a novel satellite designated PSI-Bgl was cytogenetically characterized and mapped on microchromosomes in both the centromere regions and satellite arms, but not detected on macrochromosomes [244]. This site-specific satellite compartmentalization pattern is also observed in the Mexican musk turtle (Staurotypus triporcatus, Wiegmann, 1828 [245]) and the giant musk turtle (S. salvinii, Gray, 1864 [246]) [247]. By contrast, satellites have been studied in snakes [248], lacertids [55,249-254] scincids [255,256], and varanids $[257,258]$. All satellites studied were localized to chromosomal heterochromatin, while predominantly in centromeric, pericentromeric, and/or telomeric regions. In Lacertinae, different types of satDNA repeats are characterized into different satellite families including species and genus-specific sub-families [259]. Among these, the centromeric HindIII family containing two subfamilies (I and II) constitutes $5-10 \%$ of the genome. Another family known as TaqI, possesses only interstitial sites with $2.5-5 \%$ of the genome. Differences in abundance, chromosomal position, and evolutionary rate were 
observed for the HindIII and TaqI families across lacertids. One novel AAN-TaqI satellite with an AT-enriched monomer of 187-199 bp was isolated from populations of the Atlas dwarf lizard (Atlantolacerta andreanskyi, Werner, 1929 [260]) [254]. In varanids, the VSAREP satellite has been identified in the water monitor (Varanus salvator macromaculatus, Deraniyagala, 1944 [261]) and is conserved in the genomes of Asian and Australian varanids, but not in African varanids [258,262]. This satellite family is considered to play an important role in chromosomal rearrangement in varanid lineages [258]. Three different types of heterochromatic region-linked satellite families are found in the Burmese python and habu snakes [234]. These satellite families include: (1) PFL-MspI (168 bp) from Protobothrops flavoviridis (Hallowell, 1861 [263]), (2) PBI-DdeI (196 bp), and (3) PBI-MspI (174 bp) from Python bivittatus (Kuhl, 1820 [264]). Thongchum et al. (2019) studied 40 snake species to gain an improved understanding of the conservation of PBI-DdeI satellite evolution and function. Results suggest that size-specific compartmentalization might have occurred in turtles and birds, but not in squamate reptiles [248]. Lineages with no microchromosomes like crocodiles show satDNA distribution in the centromeric region of all chromosomes. The satellite families CSI-HindIII and CSI-DraI isolated from the Siamese crocodile (Crocodylus siamensis, Schneider, 1801 [265]) were characterized in the crocodile genome, indicating their localization in the heterochromatic blocks of centromeres [102]. The CSI-HindIII family is conserved across all extant crocodile lineages of Crocodylidae, whereas the CSI-DraI satellite is known only in Crocodylus and is not represented in other crocodile genomes. A genome with a low degree of compartmentalization, which would show limited recombination and a low frequency of chromosomal rearrangements, appears to have been preserved in squamate reptiles. This observation is based on the size-specific amplified compartmentalization of satellites, such as microchromosome-specific satellites in turtles yet not in squamate reptiles. Accumulation and conservation of repeats resulted in an increase in chromosome size and number of non-deleterious insertion sites-two features that would have further hampered recombination and chromosomal rearrangements [62]. It would be interesting to determine the crucial impact of chromosomal compartmentalization with species diversity for geckos, lacertids, and the remaining groups of squamate reptiles with both macro- and microchromosomes. Crocodylia, which shows low species richness, rarely exhibits genome rearrangements among members. This suggests that the ancestral crocodilian karyotype was highly conserved with no microchromosomes [82,102]. The rate of chromosomal rearrangements may reduce over evolutionary time until genomic stability and optimal karyotypes are achieved. It is hypothesized that both compositional and structural factors of repeats may drive reptilian karyotypic evolution, with a transition from the heterozygous to the homozygous phase through a series of rearrangements. For an improved understanding of the underlying mechanisms, characterization of the specific types of rearrangements, such as cryptic inter- or intrachromosomal changes, and comparative genomic analyses in conjunction with cytogenomics or chromosomics are required to investigate genome structure across diverse reptile lineages [42]. To increase our knowledge of the dynamics and comparative landmarks of repeats, further in-depth studies are required to, firstly, understand how the scale of variability of these elements drives genome evolution, and secondly, how such variation affects processes such as gene regulation, sex chromosome evolution, and karyotype reorganization between macro- and microchromosome lineages.

Furthermore, examination of additional reptilian species is needed to elucidate the mechanisms of microchromosome inheritance during evolution. Most repeat sequences are derived from TEs, and at least $50 \%$ of the vertebrate genome appears to be derived from these sequences; researchers $[193,266]$ compared the genome sizes of birds and found a narrow range of DNA content $(2-4 \mathrm{pg})$, smaller than that found in any other vertebrate class. The questions arise: Is this due to a monophyletic origin of birds from a small ancestral genome? Or is it DNA loss due to an evolutionary constraint on genome size in birds? The monophyletic origin of birds from a small ancestral genome is supported by early studies on primitive fish [53], which suggested an ancestral genome of $50 \%$ of a 
typical mammal and a karyotype with microchromosomes. If this is true, there would be no need to propose a drastic loss of DNA during the evolution of avian microchromosomes. Why then did the avian genome remain so small and not increase in size like the genomes of mammals and reptiles? Differences in the DNA content of vertebrates are mainly due to differences in repeat content [267]. Amphibians have characteristically huge genomes, often 10 times larger than a typical mammalian genome, and repeat contents of 50-90\%. In contrast, mammals and reptiles are not so extreme and have repeat contents of 30-50\%, whereas birds have the lowest with only $15-20 \%$ repeats. These observations would suggest that the genome sizes of mammals, reptiles, and birds have been more constrained than amphibians. Furthermore, the avian genome appears to be the most constrained. Most repeat sequences are derived from TEs [222,267]. Recently, the ancestry and approximate age of TEs in the human genome were inferred from a phylogenetic analysis of the genome sequence [193]. This analysis showed that the mammalian genome increased in size 50-150 Mya through an accumulation of transposons, comprising at least 50\% of the human genome today. This analysis also showed that transposon activity virtually stopped during the past 35-50 million years. In birds, the CR1 repeats are the major retrotransposon family. Sequence analysis reveals that the avian CR1 repeat family is ancient and dying out, with about 50,000 poorly related sequences in avian genomes [268]. This is consistent with a minor role for TEs in the evolution of genome size in birds. It would be interesting to determine repeatomic variation ranges in microchromosomes of vertebrates groups, and the extent of variation at species and genus levels. Significant advances are possible through large-scale species sequencing and genome assembly.

\section{Highly Conserved Linkage Homology between Macro- and Microchromosomes and the Fusion-Fission Model of Vertebrate Evolution}

The genomes of all presently existing vertebrate species have diverged from a common ancestor over a period of several hundred million years. Comparative genomics between remote species is a key tool for the delineation of evolutionary ancestral syntenies and the process of chromosomal rearrangements [56,82,89-92,269]. To find evidence that some or all of the chicken microchromosomes arose by a process of chromosome fission or fusion, an outgroup species is needed to define the ancestral linkage homologies [259]. All the evidence suggests that some microchromosomes were already present in the common ancestor that gave rise to birds and other terrestrial vertebrates [6]. Presumably, a process of chromosome fission created the remaining avian microchromosomes [270]. Cross-species analysis on over 70 avian species from 15 different orders has revealed a remarkable lack of intermacrochromosomal rearrangements. Microchromosomes are present in all avian lineages and are assumed to be of adaptive value; otherwise, some researchers propose that they would have been lost by chance during the 100-250 million years of avian evolution [271]. The fission model predicts that avian microchromosomes may represent ancestral linkage homologies, provided that there have not been any chromosome rearrangements in this lineage [23,272-274]. Certain birds, such as the Coraciiformes, only have a few microchromosomes. Furthermore, in Falconiformes, New World falcons have 42-45 pairs of microchromosomes, whereas Old World falcons only have 12-13 pairs [275]. Chromosomal rearrangements such as fusions and fissions would have disrupted these ancestral linkage homologies. Similar cases are also observed from non-avian reptiles. Molecular phylogenetic analyses have suggested that extant sauropsids (reptiles and birds) are divided into two major groups, the lineages of Testudines (turtles), Archosauria (crocodilians and birds), and Lepidosauria (tuatara, lizards, worm lizards, snakes), although the phylogenetic position of Testudines is still debatable [275-277]. Most sauropsidan species have karyotypes consisting of macro- and microchromosomes similar to birds, except for crocodilian species whose karyotypes contain no microchromosomes $[8,9,28]$. Microchromosomes were first recorded in iguanid and teiid lizards $[58,278]$ and are considered to have originated from fragments of ancestral macrochromosomes [279]. Different reptiles possess varying numbers of microchromosomes in their chromosomal sets, and these karyotypic differences are important in reptile comparative analyses for investigating their genetic makeup [280]. 
As stated earlier, comparative genomic analyses reveal that genetic linkages were highly conserved between avians and reptilians [26,56,82,89-92,95-98,144,281]. Several crocodile and gecko chromosome pairs are composed of chromosomal segments homologous to turtle and the majority of squamate reptile microchromosomes [56,82,89-92,95-98,144,235]. By contrast, the macro- and microchromosomes of turtles are counterparts of those found in chickens, suggesting that the ancestral karyotype of Archosauromorpha, probably composed of at least eight pairs of macrochromosomes and many indistinguishable microchromosomes, has been highly conserved for more than 250 million years following their divergence from Lepidosauromorpha $[94,123,125]$. Chicken and red-eared slider (Trachemys scripta elegans, $2 n=50$ ) [282] macrochromosomes are remarkably well conserved, considering that these species shared a common ancestor (the Archosauromorpha ancestor) over 200 Mya [283]. Interestingly, the karyotypic features of the Gila monster, Heloderma suspectum, were described by Pokorná et al. (2014) consisting of $2 n=36$ chromosomes (14 macro- and 22 microchromosomes), similar to Iguania and snake karyotypes (http:/ / chromorep.univpm.it, accessed on 1 July 2021) [284,285]. A series of chromosomal fusion-fission events (centric fusion-fission, tandem fusions, insertion, and transposition), followed by centromere inactivation events between macro- or other microchromosomes, resulted in diversified karyotypes among squamate reptiles $[84,89,90,235]$. The phylogenetic placement of reptiles and birds in the presence or absence of microchromosomes suggests that the ancestral karyotype of reptiles might have contained both macro- and microchromosomes [26,144]. The microchromosomes might have disappeared by fusion between macro- and microchromosomes and/or between microchromosomes in the lineage of crocodiles. Copious evidence from BAC mapping confirms cross-species chromosomal homologies reflecting the occurrence of ancient chromosomes in an ancestral genome at least 400 Mya $[95,97,98]$. These would be cases of linkage homology disruption in the avian/reptilian lineage, either through the process of chromosomal fission or fusion. Previous research has analyzed "former" microchromosomes (i.e., those that have since fused in evolution to become part of a larger chromosome) such as those seen in Falconiformes [286,287], which largely retain their inherent microchromosomal properties such as gene density, GC content, and recombination rate in larger chromosomes [20]. In lizards (anoles) and snakes such as the Indian cobra, microchromosomal fusion has also been observed (Figure 2). Similarly, whole-genome comparisons between chickens and snakes reveal a high level of chromosomal syntenies and rearrangements. For example, the macrochromosome 1 of the Indian cobra (N. naja) has substantial homology with two macrochromosomes and two microchromosomes of chickens, indicating ancestral macrochromosomal fission (Figure 2).

In addition to amniotes, other vertebrate genomes including some primitive amphibians and lower bony fish also represent a highly dynamic number of microchromosomes. The karyotypes of Cryptobranchidae and Hynobiidae families of amphibians can carry $2 n$ chromosomes ranging from 56-66, with 14-19 pairs of microchromosomes [11,69] Chromosomal linkage homologies, as well as fission and fusion rearrangements have been detected between avian and amphibian genomes, and comparative mapping showed a considerable amount of homology between different macro- and microchromosomes $[109,288]$. Microchromosomes can also be found in chondrostean and holostean fish $(2 n=46-112)$, related to crossopterygian fish that gave rise to terrestrial vertebrates $280 \mathrm{Mya}$, with genomes similar in size to birds [53]. Lower chordates such as sea lamprey can carry exceptionally high numbers of microchromosomes, with diploid karyotypes consisting of 168 small dotlike chromosomes [289-291]. The genome-wide comparison of sea lamprey has identified ancestral conserved orthologous groups with two chicken macrochromosomes. Further analysis is required to investigate the homology of microchromosomes at different taxonomic levels of vertebrates [292]. The ubiquitous distribution of microchromosomes across different vertebrate lineages suggests that microchromosomal rearrangements appear to be characteristic of the common ancestor of terrestrial vertebrates. Furthermore, the marine chordate genome experienced 2R WGDs $\sim 450$ Mya before becoming the common ancestor 
of vertebrates and diversifying into the more than 60,000 species found today [27]. After the separation of Agnatha (jawless fish), the most primitive of vertebrates and Gnathostomata, four more fusions took place to form the ancestral Euteleostomi genome of 50 chromosomes. However, when the 2R-WGD occurred in chordates and how many rounds of WGDs occurred after $2 \mathrm{R}$ is still being debated. One study suggested that 2R-WGD might have occurred at the base of vertebrates and a 3R-WGD was followed in lampreys [293]. However, the most recent analysis based on genome comparisons of the lamprey, chicken, and gar genomes provided evidence of only a 2 R-WGD at the base of the vertebrates, followed by chromosome-scale duplications in lampreys [292]. One intriguing concern regarding the 2R-WGD was raised by comparing microchromosomes of gar and chicken [35]. In total, 12 gar and chicken microchromosomes shared considerable homology and can parsimoniously be considered ancestral to Euteleostomi. Their distribution in the tetrads resulting from the $2 \mathrm{R}$ does not follow a noticeable pattern, i.e., they are distributed among all tetrads more or less randomly. Therefore, from this comparison, it is likely that microchromosomes did not originate from a set of pre-2R microchromosomes, but only started evolving after the 1st WGD. Other studies have suggested that they emerged as an ancestral karyotype $\sim 400$ Mya in the ancestral vertebrate karyotype [6]. Bioinformatic reconstructions of avian microchromosomes have shown that they correspond directly with gnathostome ancestor protochromosomes [29], suggesting that they have remained remarkably unchanged throughout evolution. Comparative gene mapping between the genomes of chicken, human, mouse, and zebrafish revealed evidence that microchromosomes might be 400 million years old. A recent study has proposed that the typical avian-like karyotypic pattern of microchromosomes mostly emerged before birds and turtles diverged and was present in the theropod dinosaur lineage [294]. Nonetheless, the exact estimate of microchromosome origin remains unclear and further investigation of chromosome-scale assemblies using modern omics tools will be crucial to obtain in-depth insights. Unraveling the enigma of vertebrate evolution will require a deeper understanding of temporal changes in linkage homology that affect chromosome structure and function, as well as how these changes influenced and are influenced by gene and genome evolution. Knowledge gained from studying chromosome homologies will further facilitate comprehension of mechanisms that describe and drive evolutionary trajectories in vertebrates.

\section{Natural Selection and Adaptive Value for the Existence of Microchromosomes in Specific Lineages}

The gross structure and organization (at karyotypic level and in interphase nuclei) of the genome of any species have broad functional significance. The number and shape of chromosomes as well as the order of genes thereon can impact evolution in relation to phenotype and variation of that species. Amniotes diverged in a relatively short period 250-300 Mya [295,296]. When considering the karyotypic variation of vertebrates, there may be an evolutionary advantage in maintaining a karyotypic structure comprised many compact and gene-rich [294,297]. Such microchromosomes were present in all avian lineages 100-250 Mya and are assumed to be of adaptive value [271]. The interchromosomal fusion-fission processes appear to be the main driver, creating small metacentric chromosomes $[76,298,299]$. Such variation in chromosome number suggests that microchromosomes are not of any adaptive value, because most avians have 30-35 pairs of microchromosomes; hence, the process that created them must have acted before bird radiation 100 Mya [300] as an evolutionary advantage by retaining this signature avian configuration. The high frequency of microchromosomes in testudines, which represent the primitive lineage of Archosauromorpha, suggests that birds and turtles have retained the ancestral state of Archosauromorph karyotypes under similar patterns of evolutionary pressure [94]. Microchromosomes in snakes carry relatively less abundance of repeats than macrochromosomes, and analysis of localized genes enriched on microchromosomes in rattlesnakes (such as venom genes) have shown that the selection of multiple gene families through multiple tandem duplication events might have driven the evolution of microchromosomes [54]. Turtles, as ancient reptiles (older than snakes and crocodiles), have a large number of 
microchromosomes, suggesting that birds retained the ancestral state of Archosauromorph karyotypes, whereas snakes have relatively lower number of microchromosomes compared to turtles and birds. By contrast, microchromosomes are lacking in the crocodilian lineage and geckos. This evolutionary dynamics of microchromosomes, with varying occurrence across different vertebrate taxa, indicates that natural selection might have fixed these elements in each specific lineage. Several hypotheses might be postulated as to why only specific lineages contain microchromosomes.

Firstly, the primitive vertebrates that gave rise to the avian lineage had a genome size and a repeat content similar to advanced birds, and a karyotype with about 20 pairs of microchromosomes. Generally, these chromosomal changes can be rapid as proposed by the model of stasipatric speciation [24,301,302]. The rate of chromosomal rearrangement depends on both the rate of chromosomal mutation and the rate of fixation, while the rate of mutation depends on the frequency of homologous segmental sites [24]. The rate of fixation depends on many evolutionary forces, including selection, inbreeding, and genetic drift $[24,221,301,303]$. Fixation of chromosomal rearrangements during the evolutionary process created and shaped macro- and microchromosomes in specific lineages, but not randomly. If the distribution of chromosome fissions in the population were random, then the distribution of chromosome sizes in birds, turtles, and snake would tend toward one with a few large chromosomes, macrochromosomes, and many smaller chromosomes and microchromosomes. The presence of microchromosomes would suggest that a few intra- and interchromosomal rearrangements reached fixation. Notwithstanding this, cell size and genome size are correlated in vertebrates [304]. The ancestral genomes of birds, snakes, and lizards remained small or may have been reduced further in size [266,297]. Avian cells are generally smaller than mammals, and smaller cells have a higher rate of oxidative metabolism. This theory is also supported by a significant correlation between genome size and the ability to fly in mammals and birds [134]). Avian genomes may be constrained by the energetic needs for flight as a possible adaptive response. Similarly, extreme morphological and physiological adaptations in reptiles such as snakes and turtles seem to be driven by genome-wide structural variations and gross chromosomal rearrangements $[84,287,294]$. These evolutionary mechanisms reshaped the evolution of genes under positive, negative, and neutral selection. In the Burmese python, a high number of genes, functionally related to developmental processes, have been detected that experienced positive selection in ancestral snakes [305]. It remains unknown whether the majority of these positively selected genes were localized on microchromosomes that served as a genomic reservoir to facilitate the evolution of adaptive traits. Evidence of positive selection had recently been obtained by genome sequencing of the Komodo dragon (Varanus komodoensis, Ouwens, 1912 [306]), and positively selected genes have been identified in pathways related to energy metabolism, cardiovascular homoeostasis, and hemostasis [307]. Birds, turtles, and some squamate reptiles showed a high number of microchromosomes in their respective genome sizes of $\sim 1.2-1.6,1.4-2.2$, and 1.8-2.2 Gb (Table 1). The net effect of these constraints has been minimization of the repeat content in birds and turtles, while the need for a higher recombination rate on microchromosomes is another constraint that has resulted in the divergence of the properties (GC-content, repeat-content, and gene-density) of macro- and microchromosomes, thus resulting in a reduction in the DNA content of microchromosomes. With repeat-poor genomes, birds and turtles have lower potential for intrachromosomal rearrangement, and fusion/fission events are most likely. The karyotype of the common ancestor of extant sauropsids is thought to have contained both macro- and microchromosomes [6,85] although some lineages underwent frequent secondary fusion of microchromosomes resulting in no or few microchromosomes as seen in geckos, crocodiles, and the avian order Falconiformes [308,309]. If these rearrangements are fixed, they will be expected to scramble the gene content of their chromosomes and equalize the size of chromosomes. This may have been the case for most mammals, amphibians, and some reptiles with the complete absence of microchromosomes. Mammals (as descendants of reptiles), geckos, as well as crocodiles and amphibians with their larger 
and repeat-rich genomes have the potential to undergo more intra- and interchromosomal rearrangements. Ancestral genomes that gave rise to amphibian, reptilian, and mammalian lineages increased in size due to the spread and amplification of TEs. This is supported by the size of extant genomes, the fossil record, and the sequence of repeat-rich genomes such as human $[193,266,267,310]$. Essentially, this is an extension of the chromosome-based model of chromosomal rearrangement [311] in which the products of chromosome fission remain as independent chromosomes. Therefore, avian microchromosomes may be a by-product of an evolutionary process that minimizes the repeat content and genome size of birds, rather than for any specific adaptive value of these chromosomes.

Secondly, as the comparative genomic data shows, macro- and microchromosomes are derived from the same set of ancestral chromosomes given that microchromosomes code for $50 \%$ of all chicken genes which were reported sharing orthologs with various genomic regions of human [20]. The recombination frequency on microchromosomes is higher than that found in mammalian chromosomes. Furthermore, a high rate of recombination is thought to be necessary to ensure correct pairing of microchromosomes during mitosis and meiosis [110]. The need for a higher recombination rate would also have been a strong selective pressure leading to divergence in the properties of macro- and microchromosomes. Recombination rates vary broadly across populations, species, and higher taxonomic levels, suggesting that they may contribute globally to patterns of biological diversification [312]. Recombination characteristics can directly influence the processes of population divergence and speciation [313-316]. Therefore, we might expect variation in recombination rates to contribute to distinct speciation patterns observed across taxa. For instance, extensive morphological diversification sometimes coexists with shallow genetic divergence between populations. Several examples are known in birds, where striking plumage differences are characterized by little or no differentiation in molecular markers throughout most of their genomes (e.g., Vermivora warblers) [317-319], and Lonchura munias [320]. In other organisms such as snakes, genomic regions can undergo lineage-specific relaxation of selective pressure on certain genes, for instance, the Hox and Tbx limb-patterning genes support fossil evidence for successive loss of forelimbs and then hindlimbs during snake adaptive evolution [321]). Selection promoting or maintaining divergence at a few key genomic regions and gene flow homogenizing selectively neutral variation are considered the major drivers of such patterns [319]. Nevertheless, crossover frequency and distribution determine which traces, selection, and gene flow are left in genomic landscapes [322]. It is therefore plausible that a pattern of marked phenotypic diversification coexisting with a lack of genome-wide divergence can be associated with high recombination rates. However, empirical support for this connection has yet to be found. The white wagtail (Motacilla alba, Linnaeus, 1758 [162]) is a widespread passerine bird. The population structure and differentiation in molecular markers in this species are broadly incongruent with geographical variation in plumage signals, a pattern that was appropriately named "messy speciation" in a recent review of literature pertaining to speciation genomics [323]. Reasons for its long-lived success are in the realms of speculation but might be due to its ability, facilitated by many chromosomes including microchromosomes with high recombination rates, to generate variation which is thought to be the driver of natural selection. This means that a larger number of small chromosomes inherently generate variation through increased genetic recombination in addition to random chromosome segregation. Variation in meiotic recombination, such as differences in the frequency and genomic distribution of crossover events, has fundamental effects on evolutionary processes [312]). These characteristics shape associations between alleles at independent loci, thereby influencing the rate of evolutionary responses, the fate of new beneficial mutations, and the effectiveness of selection against deleterious mutations [314,324-328]. Despite the fact that a single crossover on a microchromosome would shuffle fewer functional genetic elements compared to a crossover on a macrochromosome, the effective gene density might be approximately doubled in the microchromosomes of birds [117]. Variation, in turn, facilitates adaptation and may have contributed to the wide phenotypic variation seen in birds, turtles, and snakes. By contrast, 
the tendency toward reduction of the number of microchromosomes in certain species might reflect an increase in genetic variation caused by microchromosomal fusion. However, the type of genetic material in the microchromosomes is still misunderstood and it remains to be proven that fusion of microchromosomes and more intra-microchromosomal crossover increase genetic variation as a selective advantage. However, it is plausible that microchromosomes might somehow drive species richness. For instance, living crocodilians lacking microchromosomes include only 27 species, while extant crocodilian diversity is low [329]. Furthermore, the mechanisms involved in the changes of the GC-content of the genes after the fusion of microchromosomes into the macrochromosomal complement remain unknown. It has been suggested that the GC-content is primarily influenced by local recombination rates via GC-biased gene conversion [188,312]. Under this model, A or $\mathrm{T}$ is displaced by $\mathrm{G}$ or $\mathrm{C}$ through mismatch repair when an AT/GC heteroduplex is formed at recombining regions. Accordingly, AT/GC heterozygotes produce more GC than AT gametes, thus conferring predominance of GC alleles in frequently recombining regions. Recombination rate is negatively correlated with the size of chromosome arms in the human and chicken genome $[160,330]$. Unfortunately, it is difficult to distinguish between causative and secondary effects shaping the pattern of recombination, but it remains likely that some or all of these features work synergistically.

Thirdly, intervening sequences are on average 3-4 times shorter in GC-rich than in GC-poor isochores in the chicken genome [331]. If causally related, then selection for a high recombination rate in microchromosomes will continue to increase their GC-content, reduce gene size, and repeat content, and increase gene density. A similar hypothesis has been proposed by [331] to explain why intervening sequences (and therefore genes) are smaller in GC-rich isochores. Many papers reported existing correlations between gene function and base compositions of the genes, the genomes, and the promoter regions [332-337]. The difference in global GC-content between macro- and microchromosomes may potentially cause a biased distribution of gene functions between the chromosomes: some proteins containing more amino acids for GC-rich codons due to functional constraints may be more advantageous in being encoded in microthan in macrochromosomes. By analysis of $\mathrm{dN} / \mathrm{dS}$ ratios, we demonstrated that the proteins of genes located on microchromosomes are more evolutionarily conserved. This echoes findings from a mouse-rat comparison [177] in which the $\mathrm{dN} / \mathrm{dS}$ ratio was found to be negatively correlated with GC content (and hence, recombination rate). Two potential hypotheses have been invoked to explain this observation: it could represent local variation in the efficacy of natural selection, which is known to covary with recombination rate $[327,338]$ or it could indicate that microchromosomes are enriched for slowly evolving genes that fulfill conserved functions, such as housekeeping genes.

\section{Conclusions}

Vertebrate karyotypic evolution has been extensively investigated by molecular cytogenetic techniques, providing interesting insights to unearth information about the dynamics of macro- and microchromosomes. This review emphasized the unique characteristics of microchromosomes, discussing important evolutionary aspects about their genomic origin, composition, and organization. These features suggest that microchromosomes represent ideal karyotypic components for housing genes underlying vertebrate evolution and adaptation. With the rapid development in genome sequencing technologies and advancements in bioinformatics tools, now is the ideal time to integrate cytogenetics and genomic approaches to decipher the mechanisms responsible for reshaping vertebrate genomes. Huge impacts are already being made through the availability of chromosomelevel assemblies for diverse vertebrates. These resources will provide opportunities to test hypotheses related to the role of microchromosomes in the genome evolution, the relevance of their genetic prevalence, and the mechanisms that drove the evolutionary shift from solely macrochromosomal systems to those carrying both types of chromosomes. 
Author Contributions: K.S. drafted the manuscript outline; K.S., S.F.A. and W.S. conceived the ideas; S.F.A., W.S. and T.P. prepared the figures and table; K.S., S.F.A., W.S. and T.P. contributed to reviewing the manuscript. All authors have read and agreed to the published version of the manuscript.

Funding: This study was financially supported by grants from the Thailand Research Fund (TRF) (no. RSA6180075) the National Science and Technology Development Agency (NSTDA) (NSTDA P19-52238) awarded to K.S., the e-ASIA Joint Research Program (e-ASIA JRP) (no. P1851131) awarded to K.S. and W.S., a Postdoctoral Researcher Grant at Kasetsart University awarded to S.F.A. and K.S., and a Graduate Program Scholarship from The Graduate School, Kasetsart University, Thailand awarded to T.P. and K.S.

Acknowledgments: We thank the Center for Agricultural Biotechnology (CAB) at Kasetsart University Kamphaeng Saen Campus for supporting server analysis services, and the Faculty of Science and the Faculty of Forestry at Kasetsart University for supporting research facilities. We also thank the National Biobank of Thailand (NBT) under the National Science and Technology Development Agency (NSTDA), Thailand, for supporting the high-performance computer.

Conflicts of Interest: The authors declare no conflict of interest.

\section{References}

1. Darwin, C. The Origin of Species by Means of Natural Selection, or, the Preservation of Favoured Races in the Struggle for Life; John Murray: London, UK, 1859.

2. Crandall, K.A.; Hillis, D.M. Rhodopsin evolution in the dark. Nature 1997, 387, 667-668. [CrossRef]

3. Luk, H.L.; Melaccio, F.; Rinaldi, S.; Gozem, S.; Olivucci, M. Molecular bases for the selection of the chromophore of animal rhodopsins. Proc. Natl. Acad. Sci. USA 2015, 112, 15297-15302. [CrossRef]

4. Ostrovsky, M.A. Rhodopsin: Evolution and comparative physiology. Paleontol. J. 2017, 51, 562-572. [CrossRef]

5. Shen, L.; Chen, C.; Zheng, H.; Jin, L. The evolutionary relationship between microbial rhodopsins and metazoan rhodopsins. Sci. World J. 2013, 2013, 435651. [CrossRef] [PubMed]

6. Burt, D.W. Origin and evolution of avian microchromosomes. Cytogenet. Genome Res. 2002, 96, 97-112. [CrossRef]

7. Mengden, G.A.; Stock, A.D. Chromosomal evolution in serpentes; a comparison of G and C chromosome banding patterns of some colubrid and boid genera. Chromosoma 1980, 79, 53-64. [CrossRef]

8. Olmo, E. Trends in the evolution of reptilian chromosomes. Integr. Comp. Biol. 2008, 48, 486-493. [CrossRef] [PubMed]

9. Srikulnath, K.; Thapana, W.; Muangmai, N. Role of chromosome changes in Crocodylus evolution and diversity. Genom. Inform. 2015, 13, 102. [CrossRef]

10. Morescalchi, A.; Odierna, G.; Olmo, E. Karyological relationships between the Cryptobranchid salamanders. Experientia 1977, 33, 1579-1581. [CrossRef]

11. Morescalchi, A.; Odierna, G.; Olmo, E. Karyology of the primitive slamanders, family hynobiidae. Experientia 1979, 35, 1434-1436. [CrossRef] [PubMed]

12. Stingo, V.; Rocco, L. Chondrichthyan cytogenetics: A comparison with teleosteans. J. Mol. Evol. 1991, 33, 76-82. [CrossRef]

13. Solovei, I.; Gaginskaya, E.R.; Macgregor, H.C. The arrangement and transcription of telomere DNA sequences at the ends of lampbrush chromosomes of birds. Chromosome Res. 1994, 2, 460-470. [CrossRef] [PubMed]

14. Boyes, J.W.; van Brink, J.M. Chromosomes of Syrphidae-V. Microchromosomes. Chromosoma 1970, 31, 207-216. [CrossRef]

15. Baimal, V.; Sene, F.M.; Pereira, M.A.O.R. Heterochromatin and karyotypic differentiation of some neotropical cactus-breeding species of the Drosophila repleta species group. Genetica 1983, 60, 81-92. [CrossRef]

16. Lukhtanov, V.A.; Dantchenko, A.V. Descriptions of new taxa of the genus Agrodiaetus Hübner, [1822] based on karyotype investigation. Atalanta 2002, 33, 81-107.

17. Lukhtanov, V.A. Chromosome number evolution in skippers (Lepidoptera, Hesperiidae). Comp. Cytogenet. 2014, 8, $275-291$. [CrossRef]

18. Lopes, C.; Barcellos, S.; Lemos, A.; Garnero, A.; Ribeiro, J.R.I.; Gunski, R. Belostoma estevezae Ribeiro and Alecrim (Heteroptera: Belostomatidae) reveals a new karyotype complement in Belostoma Latreille from mitotic metaphases. Rev. Chil. Entomol. 2019, 45, 31-36.

19. Groenen, M.A.M.; Cheng, H.H.; Bumstead, N.; Benkel, B.F.; Briles, W.E.; Burke, T.; Burt, D.W.; Crittenden, L.B.; Dodgson, J.; Hillel, J.; et al. A consensus linkage map of the chicken genome. Genome Res. 2000, 10, 137-147. [CrossRef]

20. Hillier, L.W.; Miller, W.; Birney, E.; Warren, W.; Hardison, R.C.; Ponting, C.P.; Bork, P.; Burt, D.W.; Groenen, M.A.M.; Delany, M.E.; et al. Sequence and comparative analysis of the chicken genome provide unique perspectives on vertebrate evolution. Nature 2004, 432, 695-716. [CrossRef]

21. Wallis, J.W.; Aerts, J.; Groenen, M.A.M.; Crooljmans, R.P.M.A.; Layman, D.; Graves, T.A.; Scheer, D.E.; Kremitzki, C.; Fedele, M.J.; Mudd, N.K.; et al. A physical map of the chicken genome. Nature 2004, 432, 761-764. [CrossRef] [PubMed]

22. Auer, H.; Mayr, B.; Lambrou, M.; Schleger, W. An extended chicken karyotype, including the NOR chromosome. Cytogenet. Genome Res. 1987, 45, 218-221. [CrossRef] [PubMed] 
23. Fillon, V. The chicken as a model to study microchromosomes in birds: A review. Genet. Sel. Evol. 1998, 30, 209-219. [CrossRef]

24. Burt, D.W.; Bruley, C.; Dunn, I.C.; Jones, C.T.; Ramage, A.; Law, A.S.; Morrice, D.R.; Paton, I.R.; Smith, J.; Windsor, D.; et al. The dynamics of chromosome evolution in birds and mammals. Nature 1999, 402, 411-413. [CrossRef]

25. Axelsson, E.; Webster, M.T.; Smith, N.G.C.; Burt, D.W.; Ellegren, H. Comparison of the chicken and turkey genomes reveals a higher rate of nucleotide divergence on microchromosomes than macrochromosomes. Genome Res. 2005, 15, 120-125. [CrossRef]

26. Solinhac, R.; Leroux, S.; Galkina, S.; Chazara, O.; Feve, K.; Vignoles, F.; Morisson, M.; Derjusheva, S.; Bed'hom, B.; Vignal, A.; et al. Integrative mapping analysis of chicken microchromosome 16 organization. BMC Genom. 2010, 11, 616. [CrossRef] [PubMed]

27. Sacerdot, C.; Louis, A.; Bon, C.; Berthelot, C.; Roest Crollius, H. Chromosome evolution at the origin of the ancestral vertebrate genome. Genome Biol. 2018, 19, 1-15. [CrossRef]

28. O'Connor, R.E.; Kiazim, L.; Skinner, B.; Fonseka, G.; Joseph, S.; Jennings, R.; Larkin, D.M.; Griffin, D.K. Patterns of microchromosome organization remain highly conserved throughout avian evolution. Chromosoma 2019, 128, 21-29. [CrossRef]

29. Nakatani, Y.; Takeda, H.; Kohara, Y.; Morishita, S. Reconstruction of the vertebrate ancestral genome reveals dynamic genome reorganization in early vertebrates. Genome Res. 2007, 17, 1254-1265. [CrossRef] [PubMed]

30. Donoghue, P. Evolution: Divining the nature of the ancestral vertebrate. Curr. Biol. 2017, 27, R277-R279. [CrossRef]

31. Lynch, V.J.; Wagner, G.P. Multiple chromosomal rearrangements structured the ancestral vertebrate Hox-bearing protochromosomes. PLoS Genet. 2009, 5, e1000349. [CrossRef] [PubMed]

32. Hubbs, C.L. A list of the lancelets of the world with diagnoses of five new species of Branchiostoma. Occas. Pap. Mus. Zool. 1922, 105, 1-16.

33. Putnam, N.H.; Butts, T.; Ferrier, D.E.K.; Furlong, R.F.; Hellsten, U.; Kawashima, T.; Robinson-Rechavi, M.; Shoguchi, E.; Terry, A.; Yu, K.; et al. The amphioxus genome and the evolution of the chordate karyotype. Nature 2008, 453, 1064-1071. [CrossRef] [PubMed]

34. Marlétaz, F.; Firbas, P.N.; Maeso, I.; Tena, J.J.; Bogdanovic, O.; Perry, M.; Wyatt, C.D.R.; de la Calle-Mustienes, E.; Bertrand, S.; Burguera, D.; et al. Amphioxus functional genomics and the origins of vertebrate gene regulation. Nature 2018, 564, 64-70. [CrossRef] [PubMed]

35. Braasch, I.; Gehrke, A.R.; Smith, J.J.; Kawasaki, K.; Manousaki, T.; Pasquier, J.; Amores, A.; Desvignes, T.; Batzel, P.; Catchen, J.; et al. The spotted gar genome illuminates vertebrate evolution and facilitates human-teleost comparisons. Nat. Genet. 2016, 48, 427-437. [CrossRef]

36. Wang, K.; de la Torre, D.; Robertson, W.E.; Chin, J.W. Programmed chromosome fission and fusion enable precise large-scale genome rearrangement and assembly. Science 2019, 365, 922-926. [CrossRef] [PubMed]

37. Gregory, T.R. Understanding natural selection: Essential concepts and common misconceptions. Evol. Educ. Outreach 2009, 2, 156-175. [CrossRef]

38. Gildenhuys, P. Natural selection. In The Stanford Encyclopedia of Philosophy, Winter 2019 ed.; Zalta, E.N., Ed.; Stanford University: Stanford, CA, USA, 2019. Available online: https:/ / plato.stanford.edu/archives/win2019/entries/natural-selection/ (accessed on 22 June 2021).

39. Rodionov, A.V. Micro versus macro: A review of structure and functions of avian micro- and macrochromosomes. Russ. J. Genet. 1996, 32, 517-527.

40. Perry, B.W.; Schield, D.R.; Adams, R.H.; Castoe, T.A. Microchromosomes exhibit distinct features of vertebrate chromosome structure and function with underappreciated ramifications for genome evolution. Mol. Biol. Evol. 2021, 38, 904-910. [CrossRef]

41. Matthey, R. Caryotypes de mammiferes et d'oiseaux. la question des microchromosomes. quelques reflexions sur l'evolution chromosomique. Arch. Genet. 1975, 48, 12-26.

42. Tegelström, H.; Ryttman, H. Chromosomes in birds (Aves): Evolutionary implications of macro-and microchromosome numbers and lengths. Hereditas 1981, 94, 225-233. [CrossRef]

43. Habermann, F.A.; Cremer, M.; Walter, J.; Kreth, G.; Von Hase, J.; Bauer, K.; Wienberg, J.; Cremer, C.; Cremer, T.; Solovei, I. Arrangements of macro- and microchromosomes in chicken cells. Chromosome Res. 2001, 9, 569-584. [CrossRef]

44. Maslova, A.V.; Krasikova, A.V. Spatial arrangement of macro-, midi-, and microchromosomes in transcriptionally active nuclei of growing oocytes in birds of the order galliformes. Cell Tissue Biol. 2011, 5, 281-293. [CrossRef]

45. Young, M.J.; O’Meally, D.; Sarre, S.D.; Georges, A.; Ezaz, T. Molecular cytogenetic map of the central bearded dragon, Pogona vitticeps (Squamata: Agamidae). Chromosome Res. 2013, 21, 361-374. [CrossRef]

46. Losada, A.; Hirano, T. Shaping the metaphase chromosome: Coordination of cohesion and condensation. BioEssays 2001, 23, 924-935. [CrossRef]

47. Antonin, W.; Neumann, H. Chromosome condensation and decondensation during mitosis. Curr. Opin. Cell Biol. 2016, 40, 15-22. [CrossRef] [PubMed]

48. Fillon, V.; Morisson, M.; Zoorob, R.; Auffray, C.; Douaire, M.; Gellin, J.; Vignal, A. Identification of 16 chicken microchromosomes by molecular markers using two-colour fluorescence in situ hybridization (FISH). Chromosome Res. 1998, 6, 307-313. [CrossRef]

49. Nishida-Umehara, C.; Ishijima, J.; Ishishita, S.; Yamada, K.; Griffin, D.K.; Yamazaki, T.; Matsuda, Y. Karyotype reorganization with conserved genomic compartmentalization in dot-shaped microchromosomes in the Japanese mountain hawk-eagle (Nisaetus nipalensis orientalis, Accipitridae). Cytogenet. Genome Res. 2013, 141, 284-294. [CrossRef] [PubMed]

50. Smith, J.; Burt, D.W. Parameters of the chicken genome (Gallus gallus). Anim. Genet. 1998, 29, 290-294. [CrossRef] [PubMed] 
51. Pichugin, A.M.; Galkina, S.A.; Potekhin, A.A.; Punina, E.O.; Rautian, M.S.; Rodionov, A.V. Estimation of the minimal size of chicken Gallus gallus domesticus microchromosomes via pulsed-field electrophoresis. Russ. J. Genet. 2001, 37, 535-538. [CrossRef]

52. Furlong, R.F. Insights into vertebrate evolution from the chicken genome sequence. Genome Biol. 2005, 6, 207. [CrossRef]

53. Ohno, S.; Muramoto, J.; Stenius, C.; Christian, L.; Kittrell, W.A.; Atkin, N.B. Microchromosomes in holocephalian, chondrostean and holostean fishes. Chromosoma 1969, 26, 35-40. [CrossRef]

54. Schield, D.R.; Card, D.C.; Hales, N.R.; Perry, B.W.; Pasquesi, G.M.; Blackmon, H.; Adams, R.H.; Corbin, A.B.; Smith, C.F.; Ramesh, B.; et al. The origins and evolution of chromosomes, dosage compensation, and mechanisms underlying venom regulation in snakes. Genome Res. 2019, 29, 590-601. [CrossRef] [PubMed]

55. Giovannotti, M.; Cerioni, P.N.; Slimani, T.; Splendiani, A.; Paoletti, A.; Fawzi, A.; Olmo, E.; Caputo Barucchi, V. Cytogenetic characterization of a population of Acanthodactylus lineomaculatus Duméril and Bibron, 1839 (Reptilia, Lacertidae), from Southwestern Morocco and insights into sex chromosome evolution. Cytogenet. Genome Res. 2017, 153, 86-95. [CrossRef]

56. Srikulnath, K.; Matsubara, K.; Uno, Y.; Nishida-Umehara, C.; Olsson, M.; Matsuda, Y. Identification of the linkage group of the $\mathrm{Z}$ sex chromosomes of the sand lizard (Lacerta agilis, Lacertidae) and elucidation of karyotype evolution in lacertid lizards. Chromosoma 2014, 123, 563-575. [CrossRef]

57. Ishijima, J.; Uno, Y.; Nunome, M.; Nishida-Umehara, C.; Kuraku, S.; Matsuda, Y. Molecular cytogenetic characterization of chromosome site-specific repetitive sequences in the Arctic lamprey (Lethenteron camtschaticum, Petromyzontidae). DNA Res. 2017, 24, 93-101. [CrossRef]

58. Deakin, J.E.; Ezaz, T. Understanding the evolution of reptile chromosomes through applications of combined cytogenetics and genomics approaches. Cytogenet. Genome Res. 2019, 157, 7-20. [CrossRef] [PubMed]

59. Masabanda, J.S.; Burt, D.W.; O’Brien, P.C.M.; Vignal, A.; Fillon, V.; Walsh, P.S.; Cox, H.; Tempest, H.G.; Smith, J.; Habermann, F.; et al. Molecular cytogenetic definition of the chicken genome: The first complete avian karyotype. Genetics 2004, 166, 1367-1373 [CrossRef]

60. Griffin, D.K.; Robertson, L.B.W.; Tempest, H.G.; Skinner, B.M. The evolution of the avian genome as revealed by comparative molecular cytogenetics. Cytogenet. Genome Res. 2007, 117, 64-77. [CrossRef] [PubMed]

61. Nishida-Umehara, C.; Ishijima, J.; Kosaka, A.; Tanabe, H.; Habermann, F.A.; Griffin, D.K.; Matsuda, Y. Characterization of chromosome structures of Falconinae (Falconidae, Falconiformes, Aves) by chromosome painting and delineation of chromosome rearrangements during their differentiation. Chromosome Res. 2008, 16, 171-181. [CrossRef]

62. Olmo, E. Rate of chromosome changes and speciation in reptiles. Genetica 2005, 125, 185-203. [CrossRef] [PubMed]

63. Valenzuela, N.; Adams, D.C. Chromosome number and sex determination coevolve in turtles. Evolution 2011, 65, 1808-1813. [CrossRef]

64. Montiel, E.E.; Badenhorst, D.; Tamplin, J.; Burke, R.L.; Valenzuela, N. Discovery of the youngest sex chromosomes reveals first case of convergent co-option of ancestral autosomes in turtles. Chromosoma 2017, 126, 105-113. [CrossRef] [PubMed]

65. Machado, C.R.D.; Domit, C.; Pucci, M.B.; Gazolla, C.B.; Glugoski, L.; Nogaroto, V.; Vicari, M.R. Heterochromatin and microsatellites detection in karyotypes of four sea turtle species: Interspecific chromosomal differences. Genet. Mol. Biol. 2020, 43, 1-9. [CrossRef]

66. Gregory, T.R. The bigger the C-value, the larger the cell: Genome size and red blood cell size in vertebrates. Blood Cells Mol. Dis. 2001, 27, 830-843. [CrossRef] [PubMed]

67. Gregory, T.R.; Witt, J.D. Population size and genome size in fishes: A closer look. Genome 2008, 51, 309-313. [CrossRef]

68. Arai, R. Fish Karyotypes: A Check List; Springer: Tokyo, Japan, 2011.

69. Morescalchi, A. Adaptation and karyotype in Amphibia. Ital. J. Zool. 1977, 44, 287-294. [CrossRef]

70. Morescalchi, A. Evolution and karyology of the Amphibians. Ital. J. Zool. 1980, 47, 113-126. [CrossRef]

71. Voss, S.R.; Kump, D.K.; Putta, S.; Pauly, N.; Reynolds, A.; Henry, R.J.; Basa, S.; Walker, J.A.; Smith, J.J. Origin of amphibian and avian chromosomes by fission, fusion, and retention of ancestral chromosomes. Genome Res. 2011, 21, 1306-1312. [CrossRef]

72. Schmid, M.; Steinlein, C.; Bogart, J.; Feichtinger, W.; León, P.; Marca, E.; Diaz, L.; Sanz, A.; Chen, S.-H.; Hedges, S. The chromosomes of Terraranan frogs. Cytogenet. Genome Res. 2010, 568, 130-131. [CrossRef]

73. Perkins, R.D.; Gamboa, J.R.; Jonika, M.M.; Lo, J.; Shum, A.; Adams, R.H.; Blackmon, H. A database of amphibian karyotypes. Chromosome Res. 2019, 27, 313-319. [CrossRef]

74. Zhang, P.; Chen, Y.-Q.; Zhou, H.; Liu, Y.-F.; Wang, X.-L.; Papenfuss, T.J.; Wake, D.B.; Qu, L.-H. Phylogeny, evolution, and biogeography of Asiatic Salamanders (Hynobiidae). Proc. Natl. Acad. Sci. USA 2006, 103, 7360-7365. [CrossRef]

75. Organ, C.L.; Shedlock, A.M.; Meade, A.; Pagel, M.; Edwards, S.V. Origin of avian genome size and structure in non-avian dinosaurs. Nature 2007, 446, 180-184. [CrossRef]

76. Tegelström, H.; Ebenhard, T.; Ryttman, H. Rate of karyotype evolution and speciation in birds. Hereditas 1983, 98, 235-239. [CrossRef] [PubMed]

77. Kapusta, A.; Suh, A.; Feschotte, C. Dynamics of genome size evolution in birds and mammals. Proc. Natl. Acad. Sci. USA 2017, 114, E1460-E1469. [CrossRef] [PubMed]

78. Ferguson-Smith, M.A.; Trifonov, V. Mammalian karyotype evolution. Nat. Rev. Genet. 2007, 8, 950-962. [CrossRef]

79. Graphodatsky, A.S.; Trifonov, V.A.; Stanyon, R. The genome diversity and karyotype evolution of mammals. Mol. Cytogenet. 2011, 4,1-16. [CrossRef] [PubMed] 
80. Gregory, T.R.; Nicol, J.A.; Tamm, H.; Kullman, B.; Kullman, K.; Leitch, L.J.; Murray, B.G.; Kapraun, D.F.; Greilhuber, J.; Bennett, M.D. Eukaryotic genome size databases. Nucleic Acids Res. 2007, 35, D332-D338. [CrossRef]

81. Gregory, T.R. Animal Genome Size Database. 2010. Available online: http:/ / www.genomesize.com $/$ results.php?page=1 (accessed on 22 June 2021).

82. Srikulnath, K.; Uno, Y.; Nishida-Umehara, C.; Ota, H.; Matsuda, Y. Karyotype reorganization in the Hokou Gecko (Gekko hokouensis, Gekkonidae): The process of microchromosome disappearance in Gekkota. PLoS ONE 2015, 10, e0134829. [CrossRef]

83. Pasquesi, G.I.M.; Adams, R.H.; Card, D.C.; Schield, D.R.; Corbin, A.B.; Perry, B.W.; Reyes-Velasco, J.; Ruggiero, R.P.; Vandewege, M.W.; Shortt, J.A. Squamate reptiles challenge paradigms of genomic repeat element evolution set by birds and mammals. Nat. Commun. 2018, 9, 1-11. [CrossRef]

84. Ahmad, S.F.; Singchat, W.; Jehangir, M.; Panthum, T.; Srikulnath, K. Consequence of paradigm shift with repeat landscapes in reptiles: Powerful facilitators of chromosomal rearrangements for diversity and evolution. Genes 2020, 11, 827. [CrossRef]

85. Norris, T.B.; Rickards, G.K.; Daugherty, C.H. Chromosomes of tuatara, Sphenodon, a chromosome heteromorphism and an archaic reptilian karyotype. Cytogenet. Genome Res. 2004, 105, 93-99. [CrossRef]

86. O'Meally, D.; Miller, H.; Patel, H.R.; Marshall Graves, J.A.; Ezaz, T. The first cytogenetic map of the Tuatara, Sphenodon punctatus. Cytogenet. Genome Res. 2009, 127, 213-223. [CrossRef]

87. Pokorná, M.J.; Altmanová, M.; Kratochvíl, L. Multiple sex chromosomes in the light of female meiotic drive in amniote vertebrates. Chromosome Res. 2014, 22, 35-44. [CrossRef]

88. Olmo, E.; Signorino, G. Chromorep: A Reptile Chromosomes Database 2005. Available online: http:/ / chromorep.univpm.it (accessed on 26 August 2017).

89. Srikulnath, K.; Matsubara, K.; Uno, Y.; Thongpan, A.; Suputtitada, S.; Apisitwanich, S.; Matsuda, Y.; Nishida-Umehara, C. Karyological characterization of the butterfly lizard (Leiolepis reevesii rubritaeniata, Agamidae, Squamata) by molecular cytogenetic approach. Cytogenet. Genome Res. 2009, 125, 213-223. [CrossRef]

90. Srikulnath, K.; Nishida-Umehara, C.; Matsubara, K.; Uno, Y.; Thongpan, A.; Suputtitada, S.; Apisitwanich, S.; Matsuda, Y. Karyotypic evolution in squamate reptiles: Comparative gene mapping revealed highly conserved linkage homology between the butterfly lizard (Leiolepis reevesii rubritaeniata, Agamidae, Lacertilia) and the Japanese four-striped rat snake (Elaphe quadrivirgata, Colubridae, Serpentes). Chromosome Res. 2009, 17, 975-986. [CrossRef]

91. Srikulnath, K.; Uno, Y.; Matsubara, K.; Thongpan, A.; Suputtitada, S.; Apisitwanich, S.; Nishida-Umehara, C.; Matsuda, Y. Chromosomal localization of the 18S-28S and 5s rRNA genes and (TTAGGG) n sequences of butterfly lizards (Leiolepis belliana belliana and Leiolepis boehmei, Agamidae, Squamata). Genet. Mol. Biol. 2011, 34, 583-586. [CrossRef]

92. Srikulnath, K.; Uno, Y.; Nishida-Umehara, C.; Matsuda, Y. Karyotype evolution in monitor lizards: Cross-species chromosome mapping of cDNA reveals highly conserved synteny and gene order in the Toxicofera clade. Chromosome Res. 2013, 21, 805-819. [CrossRef] [PubMed]

93. Srikulnath, K.; Azad, B.; Singchat, W.; Ezaz, T. Distribution and amplification of interstitial telomeric sequences (ITSs) in Australian dragon lizards support frequent chromosome fusions in Iguania. PLoS ONE 2019, 14, e0212683. [CrossRef] [PubMed]

94. Uno, Y.; Nishida-Umehara, C.; Tarui, H.; Ishishita, S.; Takagi, C.; Nishimura, O.; Ishijima, J.; Ota, H.; Kosaka, A.; Matsubara, K.; et al. Inference of the protokaryotypes of amniotes and tetrapods and the evolutionary processes of microchromosomes from comparative gene mapping. PLoS ONE 2012, 7, e53027. [CrossRef] [PubMed]

95. Singchat, W.; O'Connor, R.E.; Tawichasri, P.; Suntronpong, A.; Sillapaprayoon, S.; Suntrarachun, S.; Muangmai, N.; Baicharoen, S.; Peyachoknagul, S.; Chanhome, L.; et al. Chromosome map of the Siamese cobra: Did partial synteny of sex chromosomes in the amniote represent "A hypothetical ancestral super-sex chromosome" or random distribution? BMC Genom. 2018, 19, 939. [CrossRef] [PubMed]

96. Singchat, W.; Ahmad, S.F.; Laopichienpong, N.; Suntronpong, A.; Panthum, T.; Griffin, D.K.; Srikulnath, K. Snake W sex chromosome: The shadow of ancestral amniote super-sex chromosome. Cells 2020, 9, 2386. [CrossRef]

97. Singchat, W.; Ahmad, S.F.; Sillapaprayoon, S.; Muangmai, N.; Duengkae, P.; Peyachoknagul, S.; O’Connor, R.E.; Griffin, D.K.; Srikulnath, K. Partial amniote sex chromosomal linkage homologies shared on snake W sex chromosomes support the ancestral super-sex chromosome evolution in amniotes. Front. Genet. 2020, 11, 948. [CrossRef] [PubMed]

98. Singchat, W.; Sillapaprayoon, S.; Muangmai, N.; Baicharoen, S.; Indananda, C.; Duengkae, P.; Peyachoknagul, S.; O'Connor, R.E.; Griffin, D.K.; Srikulnath, K. Do sex chromosomes of snakes, monitor lizards, and Iguanian lizards result from multiple fission of an "ancestral amniote super-sex chromosome"? Chromosome Res. 2020, 28, 209-228. [CrossRef] [PubMed]

99. Pinthong, K.; Tanomtong, A.; Getlekha, N.; Sangpadee, W.; Sangpakdee, K.; Sanoamuang, L. First cytogenetic study of puff-faced water snake, Homalopsis buccata (Squamata, Colubridae) by conventional staining, Ag-NOR banding and GTGbanding techniques. Cytologia 2013, 78, 141-150. [CrossRef]

100. Matsubara, K.; Knopp, T.; Sarre, S.D.; Georges, A.; Ezaz, T. Karyotypic analysis and FISH mapping of microsatellite motifs reveal highly differentiated XX/XY sex chromosomes in the pink-tailed worm-lizard (Aprasia parapulchella, Pygopodidae, Squamata). Mol. Cytogenet. 2013, 6, 1-7. [CrossRef]

101. Cohen, M.M.; Clark, H.F. The somatic chromosomes of five crocodilian s pecies. Cytogenet. Genome Res. 1967, 6, 193-203. [CrossRef] 
102. Kawagoshi, T.; Nishida-Umehara, C.; Ota, H.; Kumazawa, Y.; Endo, H.; Matsuda, Y. Molecular structures of centromeric heterochromatin and karyotypic evolution in the Siamese crocodile (Crocodylus siamensis) (Crocodylidae, Crocodylia). Chromosome Res. 2008, 16, 1119-1132. [CrossRef]

103. Nirchio, M.; Rossi, A.R.; Foresti, F.; Oliveira, C. Chromosome evolution in fishes: A new challenging proposal from Neotropical species. Neotrop. Ichthyol. 2014, 12, 761-770. [CrossRef]

104. Salvador, L.B.; Moreira-Filho, O. B chromosomes in Astyanax scabripinnis (Pisces, Characidae). Heredity 1992, 69, 50-56. [CrossRef]

105. Kavalco, K.F.; De Almeida-Toledo, L.F. Molecular cytogenetics of blind Mexican tetra and comments on the karyotypic characteristics of genus Astyanax (Teleostei, Characidae). Zebrafish 2007, 4, 103-111. [CrossRef]

106. Ahmad, S.F.; Jehangir, M.; Cardoso, A.L.; Wolf, I.R.; Margarido, V.P.; Cabral-De-Mello, D.C.; O’Neill, R.; Valente, G.T.; Martins, C. $\mathrm{B}$ chromosomes of multiple species have intense evolutionary dynamics and accumulated genes related to important biological processes. BMC Genom. 2020, 21, 656. [CrossRef]

107. Smith, J.J.; Voss, S.R. Gene order data from a model amphibian (Ambystoma): New perspectives on vertebrate genome structure and evolution. BMC Genom. 2006, 7, 219. [CrossRef] [PubMed]

108. Session, A.M.; Uno, Y.; Kwon, T.; Chapman, J.A.; Toyoda, A.; Takahashi, S.; Fukui, A.; Hikosaka, A.; Suzuki, A.; Kondo, M.; et al. Genome evolution in the allotetraploid frog Xenopus laevis. Nature 2016, 538, 336-343. [CrossRef] [PubMed]

109. Ma, W.J.; Veltsos, P. The diversity and evolution of sex chromosomes in frogs. Genes 2021, 12, 483. [CrossRef] [PubMed]

110. Rodionov, A.V.; Chelysheva, L.A.; Solovei, I.V.; Myakoshina Yu, A. Chiasma distribution in the lambrush chromosomes of the chicken Gallus gallus domesticus. Hot spots of recombination and their feasible role in proper disjunction of homologous chromosome at the first meiotic division. Genetika 1992, 28, 151-160. [PubMed]

111. Backström, N.; Forstmeier, W.; Schielzeth, H.; Mellenius, H.; Nam, K.; Bolund, E.; Webster, M.T.; Öst, T.; Schneider, M.; Kempenaers, B.; et al. The recombination landscape of the zebra finch Taeniopygia guttata genome. Genome Res. 2010, 20, 485-495. [CrossRef]

112. Schield, D.R.; Pasquesi, G.I.M.; Perry, B.W.; Adams, R.H.; Nikolakis, Z.L.; Westfall, A.K.; Orton, R.W.; Meik, J.M.; MacKessy, S.P.; Castoe, T.A.; et al. Snake recombination landscapes are concentrated in functional regions despite PRDM9. Mol. Biol. Evol. 2020, 37, 1272-1294. [CrossRef] [PubMed]

113. McQueen, H.A.; Fantes, J.; Cross, S.H.; Clark, V.H.; Archibald, A.L.; Bird, A.P. CpG islands of chicken are concentrated on microchromosomes. Nat. Genet. 1996, 12, 321-324. [CrossRef]

114. Grützner, F.; Zend-Ajusch, E.; Stout, K.; Munsche, S.; Niveleau, A.; Nanda, I.; Schmid, M.; Haaf, T. Chicken microchromosomes are hypermethylated and can be identified by specific painting probes. Cytogenet. Genome Res. 2001, 93, 265-269. [CrossRef]

115. Andreozzi, L.; Federico, C.; Motta, S.; Saccone, S.; Sazanova, A.L.; Sazanov, A.A.; Smirnov, A.F.; Galkina, S.A.; Lukina, N.A.; Rodionov, A.V.; et al. Compositional mapping of chicken chromosomes and identification of the gene-richest regions. Chromosome Res. 2001, 9, 521-532. [CrossRef]

116. McQueen, H.A.; Siriaco, G.; Bird, A.P. Chicken microchromosomes are hyperacetylated, early replicating, and gene rich. Genome Res. 1998, 8, 621-630. [CrossRef] [PubMed]

117. Smith, J.; Bruley, C.K.; Paton, I.R.; Dunn, I.; Jones, C.T.; Windsor, D.; Morrice, D.R.; Law, A.S.; Masabanda, J.; Sazanov, A.; et al. Differences in gene density on chicken macrochromosomes and microchromosomes. Anim. Genet. 2000, 31, 96-103. [CrossRef] [PubMed]

118. Smith, C.A.; Clifford, V.; Western, P.S.; Wilcox, S.A.; Bell, K.S.; Sinclair, A.H. Cloning and expression of a DAX1 homologue in the chicken embryo. J. Mol. Endocrinol. 2000, 24, 23-32. [CrossRef]

119. Schmid, M.; Enderle, E.; Schindler, D.; Schempp, W. Chromosome banding and DNA replication patterns in bird karyotypes. Cytogenet. Genome Res. 1989, 52, 139-146. [CrossRef]

120. Li, X.Q.; Du, D. Variation, evolution, and correlation analysis of $\mathrm{C}+\mathrm{G}$ content and genome or chromosome size in different kingdoms and phyla. PLoS ONE 2014, 9, e88339. [CrossRef]

121. Piovesan, A.; Pelleri, M.C.; Antonaros, F.; Strippoli, P.; Caracausi, M.; Vitale, L. On the length, weight and GC content of the human genome. BMC Res. Notes 2019, 12, 106. [CrossRef]

122. Borůvková, V.; Howell, W.M.; Matoulek, D.; Symonová, R. Quantitative approach to fish cytogenetics in the context of vertebrate genome evolution. Genes 2021, 12, 312. [CrossRef]

123. Matsubara, K.; Kuraku, S.; Tarui, H.; Nishimura, O.; Nishida-Umehara, C.; Agata, K.; Kumazawa, Y.; Matsuda, Y. Intra-genomic GC heterogeneity in sauropsids: Evolutionary insights from cDNA mapping and $\mathrm{GC}_{3}$ profiling in snake. BMC Genom. 2012, 13, 604. [CrossRef] [PubMed]

124. Skinner, B.M.; Robertson, L.B.W.; Tempest, H.G.; Langley, E.J.; Ioannou, D.; Fowler, K.E.; Crooijmans, R.P.M.A.; Hall, A.D.; Griffin, D.K.; Völker, M. Comparative genomics in chicken and Pekin duck using FISH mapping and microarray analysis. BMC Genom. 2009, 10, 357. [CrossRef]

125. Matsuda, Y.; Nishida-Umehara, C.; Tarui, H.; Kuroiwa, A.; Yamada, K.; Isobe, T.; Ando, J.; Fujiwara, A.; Hirao, Y.; Nishimura, O.; et al. Highly conserved linkage homology between birds and turtles: Bird and turtle chromosomes are precise counterparts of each other. Chromosome Res. 2005, 13, 601-615. [CrossRef]

126. Bista, B.; Valenzuela, N. Turtle insights into the evolution of the reptilian karyotype and the genomic architecture of sex determination. Genes 2020, 11, 416. [CrossRef] [PubMed] 
127. GBIF Secretariat. Pelodiscus sinensis (Wiegmann, 1835). GBIF Backbone Taxonomy. Available online: https://www.gbif.org/ species/5220435 (accessed on 22 June 2021).

128. Kawagoshi, T.; Uno, Y.; Matsubara, K.; Matsuda, Y.; Nishida-Umehara, C. The ZW micro-sex chromosomes of the Chinese soft-shelled turtle (Pelodiscus sinensis, Trionychidae, Testudines) have the same origin as chicken chromosome 15. Cytogenet. Genome Res. 2009, 125, 125-131. [CrossRef] [PubMed]

129. Warren, W.C.; Hillier, L.D.W.; Tomlinson, C.; Minx, P.; Kremitzki, M.; Graves, T.; Markovic, C.; Bouk, N.; Pruitt, K.D.; ThibaudNissen, F.; et al. A new chicken genome assembly provides insight into avian genome structure. G3 Genes Genomes Genet. 2017, 7, 109-117. [CrossRef] [PubMed]

130. Yamada, K.; Nishida-Umehara, C.; Matsuda, Y. Characterization and chromosomal distribution of novel satellite DNA sequences of the lesser rhea (Pterocnemia pennata) and the greater rhea (Rhea americana). Chromosome Res. 2002, 10, 513-523. [CrossRef] [PubMed]

131. Yamada, K.; Nishida-Umehara, C.; Matsuda, Y. Erratum: A new family of satellite DNA sequences as a major component of centromeric heterochromatin in owls (Strigiformes). Chromosoma 2004, 112, 372-373. [CrossRef]

132. GBIF Secretariat. Trachemys scripta Subsp. elegans (Wied, 1838). GBIF Backbone Taxonomy. Available online: https://www.gbif. org/species / 6157026 (accessed on 22 June 2021).

133. Laurenti, J.N. Specimen Medicum, Exhibens Synopsin Reptilium Emendatam cum Experimentis Circa Venena et Antidota Reptilium Austracorum, Quod Authoritate et Consensu; Joan. Thomae: Vienna, Austria, 1768; p. 217.

134. Hughes, S.; Zelus, D.; Mouchiroud, D. Warm-blooded isochore structure in Nile crocodile and turtle. Mol. Biol. Evol. 1999, 16, 1521-1527. [CrossRef]

135. Chojnowski, J.L.; Franklin, J.; Katsu, Y.; Iguchi, T.; Guillette, L.J.; Kimball, R.T.; Braun, E.L. Patterns of vertebrate isochore evolution revealed by comparison of expressed mammalian, avian, and crocodilian genes. J. Mol. Evol. 2007, 65, 259-266. [CrossRef]

136. Chojnowski, J.L.; Braun, E.L. Turtle isochore structure is intermediate between amphibians and other amniotes. Integr. Comp. Biol. 2008, 48, 454-462. [CrossRef]

137. Melodelima, C.; Gautier, C. The GC-heterogeneity of teleost fishes. BMC Genom. 2008, 9, 632. [CrossRef]

138. Matoulek, D.; Boruvkova, V.; Ocalewicz, K.; Symonova, R. GC and repeats profiling along chromosomes-The future of fish compositional cytogenomics. Genes 2021, 12, 50. [CrossRef]

139. Holbrook, J.E. North American Herpetology: Or a Description of the Reptiles Inhabiting the United States, 2nd ed.; J. Dobson: Philadelphia, PA, USA, 1842; Volume II, p. 142.

140. St John, J.A.; Braun, E.L.; Isberg, S.R.; Miles, L.G.; Chong, A.Y.; Gongora, J.; Dalzell, P.; Moran, C.; Bed'hom, B.; Abzhanov, A.; et al. Sequencing three crocodilian genomes to illuminate the evolution of archosaurs and amniotes. Genome Biol. 2012, 13, 415. [CrossRef]

141. Margres, M.J.; Rautsaw, R.M.; Strickland, J.L.; Mason, A.J.; Schramer, T.D.; Hofmann, E.P.; Stiers, E.; Ellsworth, S.A.; Nystrom, G.S.; Hogan, M.P.; et al. The Tiger Rattlesnake genome reveals a complex genotype underlying a simple venom phenotype. Proc. Natl. Acad. Sci. USA 2021, 118, e2014634118. [CrossRef]

142. Boie, H. Merkmale einiger japanischer Lurche. Lsis Oken 1826, 18-19, 203-216.

143. Cuvier, G.; Voigt, F.S. Das Thierreich, Geordnet Nach Seiner Organisation: Nach der Zweiten Ausgabe Übersetzt und Durch Zusätze Erweitert von F.S. Voigt; Brockhaus: Leipzig, Germany, 1832; Volume 2, p. 539.

144. Alföldi, J.; Di Palma, F.; Grabherr, M.; Williams, C.; Kong, L.; Mauceli, E.; Russell, P.; Lowe, C.B.; Glor, R.E.; Jaffe, J.D.; et al. The genome of the green anole lizard and a comparative analysis with birds and mammals. Nature 2011, 477, 587-591. [CrossRef]

145. Brandley, M.C.; Wynn, A.; De Queiroz, K. Karyotype and relationships of Anolis desechensis. J. Herpetol. 2006, 40, 136-139. [CrossRef]

146. Figuet, E.; Ballenghien, M.; Romiguier, J.; Galtier, N. Biased gene conversion and GC-content evolution in the coding sequences of reptiles and vertebrates. Genome Biol. Evol. 2015, 7, 240-250. [CrossRef]

147. Pyron, R.A.; Burbrink, F.T.; Wiens, J.J. A phylogeny and revised classification of Squamata, including 4161 species of lizards and snakes. BMC Evol. Biol. 2013, 13, 93. [CrossRef] [PubMed]

148. Romiguier, J.; Ranwez, V.; Douzery, E.J.P.; Galtier, N. Contrasting GC-content dynamics across 33 mammalian genomes: Relationship with life-history traits and chromosome sizes. Genome Res. 2010, 20, 1001-1009. [CrossRef] [PubMed]

149. Rao, Y.S.; Chai, X.W.; Wang, Z.F.; Nie, Q.H.; Zhang, X.Q. Impact of GC content on gene expression pattern in chicken. Genet. Sel. Evol. 2013, 45, 1-7. [CrossRef]

150. Hunter, N. Meiotic recombination: The essence of heredity. Cold Spring Harb. Perspect. Biol. 2015, 7, a016618. [CrossRef]

151. Kawakami, T.; Smeds, L.; Backström, N.; Husby, A.; Qvarnström, A.; Mugal, C.F.; Olason, P.; Ellegren, H. A high-density linkage map enables a second-generation collared flycatcher genome assembly and reveals the patterns of avian recombination rate variation and chromosomal evolution. Mol. Ecol. 2014, 23, 4035-4058. [CrossRef]

152. Borrie, M.S.; Campor, J.S.; Joshi, H.; Gartenberg, M.R. Binding, sliding, and function of cohesin during transcriptional activation. Proc. Natl. Acad. Sci. USA 2017, 114, E1062-E1071. [CrossRef]

153. Mieczkowski, P.A.; Lemoine, F.J.; Petes, T.D. Recombination between retrotransposons as a source of chromosome rearrangements in the yeast Saccharomyces cerevisiae. DNA Repair 2006, 5, 1010-1020. [CrossRef] 
154. Ito, M.; Kugou, K.; Fawcett, J.A.; Mura, S.; Ikeda, S.; Innan, H.; Ohta, K. Meiotic recombination cold spots in chromosomal cohesion sites. Genes Cells 2014, 19, 359-373. [CrossRef] [PubMed]

155. Merkenschlager, M. Cohesin: A global player in chromosome biology with local ties to gene regulation. Curr. Opin. Genet. Dev. 2010, 20, 555-561. [CrossRef]

156. Craig, J.M.; Bickmore, W.A. The distribution of CpG islands in mammalian chromosomes. Nat. Genet. 1994, 7, 376-382. [CrossRef] [PubMed]

157. Baudat, F.; Massy, B. Regulating double-stranded DNA break repair towards crossover or non-crossover during mammalian meiosis. Chromosome Res. 2007, 15, 565-577. [CrossRef] [PubMed]

158. Baudat, F.; Imai, Y.; Massy, B. Meiotic recombination in mammals: Localization and regulation. Nat. Rev. Genet. 2013, 14, 794-806. [CrossRef] [PubMed]

159. GBIF Secretariat. Anser anser (Linnaeus, 1758). GBIF Backbone Taxonomy. Available online: https://www.gbif.org/species/2498 036 (accessed on 22 June 2021).

160. Groenen, M.A.M.; Wahlberg, P.; Foglio, M.; Cheng, H.H.; Megens, H.J.; Crooijmans, R.P.M.A.; Besnier, F.; Lathrop, M.; Muir, W.M.; Wong, G.K.S.; et al. A high-density SNP-based linkage map of the chicken genome reveals sequence features correlated with recombination rate. Genome Res. 2009, 19, 510-519. [CrossRef] [PubMed]

161. Torgasheva, A.A.; Borodin, P.M. Immunocytological analysis of meiotic recombination in the gray goose (Anser anser). Cytogenet. Genome Res. 2017, 151, 27-35. [CrossRef]

162. Motacilla alba Linnaeus, 1758. Available online: https://www.gbif.org/species/9599502 (accessed on 22 June 2021 ).

163. Pigozzi, M.I. Distribution of MLH1 foci on the synaptonemal complexes of chicken oocytes. Cytogenet. Cell Genet. 2001, 95, 129-133. [CrossRef]

164. Marais, G. Biased gene conversion: Implications for genome and sex evolution. Trends Genet. 2003, 19, 330-338. [CrossRef]

165. Lercher, M.J.; Urrutia, A.O.; Pavlíček, A.; Hurst, L.D. A unification of mosaic structures in the human genome. Hum. Mol. Genet. 2003, 12, 2411-2415. [CrossRef]

166. Sémon, M.; Mouchiroud, D.; Duret, L. Relationship between gene expression and GC-content in mammals: Statistical significance and biological relevance. Hum. Mol. Genet. 2005, 14, 421-427. [CrossRef] [PubMed]

167. Bickmore, W.A. Patterns in the genome. Heredity 2019, 123, 50-57. [CrossRef] [PubMed]

168. Turner, B.M. Decoding the nucleosome. Cell 1993, 75, 5-8. [CrossRef]

169. Wade, P.A.; Pruss, D.; Wolffe, A.P. Histone acetylation: Chromatin in action. Trends Biochem. Sci. 1997, 22, 128-132. [CrossRef]

170. Grunstein, M. Histone acetylation in chromatin structure and transcription. Nature 1997, 389, 349-352. [CrossRef] [PubMed]

171. Jeppesen, P.; Mitchell, A.; Turner, B.; Perry, P. Antibodies to defined histone epitopes reveal variations in chromatin conformation and underacetylation of centric heterochromatin in human metaphase chromosomes. Chromosoma 1992, 101, 322-332. [CrossRef]

172. Jeppesen, P.; Turner, B.M. The inactive $\mathrm{X}$ chromosome in female mammals is distinguished by a lack of histone H4 acetylation, a cytogenetic marker for gene expression. Cell 1993, 74, 281-289. [CrossRef]

173. Ronzoni, S.; Faretta, M.; Ballarini, M.; Pelicci, P.G.; Minucci, S. New method to detect histone acetylation levels by flow cytometry. Cytom. A 2005, 66, 52-61. [CrossRef]

174. van Leeuwen, F.; van Steensel, B. Histone modifications: From genome-wide maps to functional insights. Genome Biol. 2005, 6, 1-6. [CrossRef]

175. Eyre-Walker, A. Recombination and mammalian genome evolution. Proc. R. Soc. B 1993, 252, 237-243. [CrossRef]

176. Bielawski, J.P.; Dunn, K.A.; Yang, Z. Rates of nucleotide substitution and mammalian nuclear gene evolution: Approximate and maximum-likelihood methods lead to different conclusions. Genetics 2000, 156, 1299-1308. [CrossRef]

177. Hurst, L.D.; Williams, E.J.B. Covariation of GC content and the silent site substitution rate in rodents: Implications for methodology and for the evolution of isochores. Gene 2000, 261, 107-114. [CrossRef]

178. Smith, N.G.C.; Webster, M.T.; Ellegren, H. Deterministic mutation rate variation in the human genome. Genome Res. 2002, 12, 1350-1356. [CrossRef] [PubMed]

179. Sachidanandam, R.; Weissman, D.; Schmidt, S.C.; Kakol, J.M.; Stein, L.D.; Marth, G.; Sherry, S.; Mullikin, J.C.; Mortimore, B.J.; Willey, D.L.; et al. A map of human genome sequence variation containing 1.42 million single nucleotide polymorphisms. Nature 2001, 409, 928-934. [CrossRef]

180. Zhao, Z.; Boerwinkle, E. Neighboring-nucleotide effects on single nucleotide polymorphisms: A study of 2.6 million polymorphisms across the human genome. Genome Res. 2002, 12, 1679-1686. [CrossRef]

181. Lercher, M.J.; Hurst, L.D. Human SNP variability and mutation rate are higher in regions of high recombination. Trends Genet. 2002, 18, 337-340. [CrossRef]

182. Waterston, R.H.; Pachter, L. Initial sequencing and comparative analysis of the mouse genome. Nature 2002, $420,520-562$. [CrossRef] [PubMed]

183. Hellmann, I.; Ebersberger, I.; Ptak, S.E.; Pääbo, S.; Przeworski, M. A neutral explanation for the correlation of diversity with recombination rates in humans. Am. J. Hum. Genet. 2003, 72, 1527-1535. [CrossRef] [PubMed]

184. Jensen-Seaman, M.I.; Furey, T.S.; Payseur, B.A.; Lu, Y.; Roskin, K.M.; Chen, C.F.; Thomas, M.A.; Haussler, D.; Jacob, H.J. Comparative recombination rates in the rat, mouse, and human genomes. Genome Res. 2004, 14, 528-538. [CrossRef]

185. McVean, G.A.T.; Myers, S.R.; Hunt, S.; Deloukas, P.; Bentley, D.R.; Donnelly, P. The fine-scale structure of recombination rate variation in the human genome. Science 2004, 304, 581-584. [CrossRef] 
186. Strathern, J.N.; Shafer, B.K.; McGill, C.B. DNA synthesis errors associated with double-strand-break repair. Genetics 1995, 140, 965-972. [CrossRef]

187. Kong, A.; Gudbjartsson, D.F.; Sainz, J.; Jonsdottir, G.M.; Gudjonsson, S.A.; Richardsson, B.; Sigurdardottir, S.; Barnard, J.; Hallbeck, B.; Masson, G.; et al. A high-resolution recombination map of the human genome. Nat. Genet. 2002, 31, 241-247. [CrossRef]

188. Meunier, J.; Duret, L. Recombination drives the evolution of GC-content in the human genome. Mol. Biol. Evol. 2004, 21, 984-990. [CrossRef] [PubMed]

189. Caron, H.; Van Schaik, B.; Van der Mee, M.; Baas, F.; Riggins, G.; Van Sluis, P.; Hermus, M.C.; Van Asperen, R.; Boon, K.; Voûte, P.A.; et al. The human transcriptome map: Clustering of highly expressed genes in chromosomal domains. Science 2001, 291, 1289-1292. [CrossRef] [PubMed]

190. Eyre-Walker, A.; Hurst, L.D. The evolution of isochores. Nat. Rev. Genet. 2001, 2, 549-555. [CrossRef]

191. Lercher, M.J.; Urrutia, A.O.; Hurst, L.D. Clustering of housekeeping genes provides a unified model of gene order in the human genome. Nat. Genet. 2002, 31, 180-183. [CrossRef]

192. Lercher, M.J.; Chamary, J.; Hurst, L.D. Genomic regionality in rates of evolution is not explained by clustering of genes of comparable expression profile. Genome Res. 2004, 14, 1002-1013. [CrossRef]

193. Lander, E.S.; Linton, L.M.; Birren, B.; Nusbaum, C.; Zody, M.C.; Baldwin, J.; Devon, K.; Dewar, K.; Doyle, M.; FitzHugh, W.; et al. International Human Genome Sequencing Consortium, 409 3. J. Am. Med. Inform. Assoc. 2003, 412, 11-12.

194. Axelsson, E.; Smith, N.G.C.; Sundström, H.; Berlin, S.; Ellegren, H. Male-biased mutation rate and divergence in autosomal, Z-linked and W-linked introns of chicken and turkey. Mol. Biol. Evol. 2004, 21, 1538-1547. [CrossRef]

195. Chuang, J.H.; Li, H. Functional bias and spatial organization of genes in mutational hot and cold regions in the human genome. PLoS Biol. 2004, 2, e29. [CrossRef]

196. Webster, M.T.; Smith, N.G.C.; Lercher, M.J.; Ellegren, H. Gene expression, synteny, and local similarity in human noncoding mutation rates. Mol. Biol. Evol. 2004, 21, 1820-1830. [CrossRef]

197. Robertson, K.D.; Wolffe, A.P. DNA methylation in health and disease. Nat. Rev. Genet. 2000, 1, 11-19. [CrossRef]

198. Piganeau, G.D.; Mouchiroud, D.L.; Gautier, C. Expected relationship between the silent substitution rate and the GC content: Implications for the evolution of isochores. J. Mol. Evol. 2002, 54, 129-133. [CrossRef]

199. Nabholz, B.; Glémin, S.; Galtier, N. Strong variations of mitochondrial mutation rate across mammals-The longevity hypothesis. Mol. Biol. Evol. 2008, 25, 120-130. [CrossRef]

200. Nabholz, B.; Glemin, S.; Galtier, N. The erratic mitochondrial clock: Variations of mutation rate, not population size, affect mtDNA diversity across birds and mammals. BMC Evol. Biol. 2009, 9, 54. [CrossRef]

201. Lourenço, J.M.; Glémin, S.; Chiari, Y.; Galtier, N. The determinants of the molecular substitution process in turtles. J. Evol. Biol. 2013, 26, 38-50. [CrossRef]

202. Bourgeois, Y.; Boissinot, S. On the population dynamics of junk: A review on the population genomics of transposable elements. Genes 2019, 10, 419. [CrossRef]

203. Federico, C.; Cantarella, C.D.; Scavo, C.; Saccone, S.; Bed'Hom, B.; Bernardi, G. Avian genomes: Different karyotypes but a similar distribution of the GC-richest chromosome regions at interphase. Chromosome Res. 2005, 13, 785-793. [CrossRef]

204. Berner, D.; Roesti, M. Genomics of adaptive divergence with chromosome-scale heterogeneity in crossover rate. Mol. Ecol. 2017, 26, 6351-6369. [CrossRef]

205. Haenel, Q.; Laurentino, T.G.; Roesti, M.; Berner, D. Meta-analysis of chromosome-scale crossover rate variation in eukaryotes and its significance to evolutionary genomics. Mol. Ecol. 2018, 27, 2477-2497. [CrossRef]

206. Ferreira, J.; Paolella, G.; Ramos, C.; Lamond, A.I. Spatial organization of large-scale chromatin domains in the nucleus: A magnified view of single chromosome territories. J. Cell Biol. 1997, 139, 1597-1610. [CrossRef]

207. Sadoni, N.; Langer, S.; Fauth, C.; Bernardi, G.; Cremer, T.; Turner, B.M.; Zink, D. Nuclear organization of mammalian genomes: Polar chromosome territories build up functionally distinct higher order compartments. J. Cell Biol. 1999, 146, 1211-1226. [CrossRef]

208. GBIF Secretariat. Taeniopygia guttata (Vieillot, 1817). GBIF Backbone Taxonomy. Available online: https://www.gbif.org/species/ 2493633 (accessed on 22 June 2021).

209. Calderón, P.L.; Pigozzi, M.I. MLH1-focus mapping in birds shows equal recombination between sexes and diversity of crossover patterns. Chromosome Res. 2006, 14, 605-612. [CrossRef]

210. Semenov, G.A.; Koblik, E.A.; Red'kin, Y.A.; Badyaev, A.V. Extensive phenotypic diversification coexists with little genetic divergence and a lack of population structure in the White Wagtail subspecies complex (Motacilla alba). J. Evol. Biol. 2018, 31, 1093-1108. [CrossRef]

211. Rice, J.C.; Allis, C.D. Histone methylation versus histone acetylation: New insights into epigenetic regulation. Curr. Opin. Cell Biol. 2001, 13, 263-273. [CrossRef]

212. Wade, P.A. Methyl CpG binding proteins: Coupling chromatin architecture to gene regulation. Oncogene 2001, 20, 3166-3173. [CrossRef]

213. Pyrpasopoulou, A.; Meier, J.; Maison, C.; Simos, G.; Georgatos, S.D. The lamin B receptor (LBR) provides essential chromatin docking sites at the nuclear envelope. EMBO J. 1996, 15, 7108-7119. [CrossRef]

214. Schermelleh, L.; Solovei, I.; Zink, D.; Cremer, T. Two-color fluorescence labeling of early and mid-to-late replicating chromatin in living cells. Chromosome Res. 2001, 9, 77-80. [CrossRef] 
215. de Leon, F.A.P.; Li, Y.; Weng, Z. Early and late replicative chromosomal banding patterns of Gallus domesticus. J. Hered. 1992, 83, 36-42. [CrossRef]

216. Berchtold, D.; Fesser, S.; Bachmann, G.; Kaiser, A.; Eilert, J.C.; Frohns, F.; Sadoni, N.; Muck, J.; Kremmer, E.; Eick, D.; et al. Nuclei of chicken neurons in tissues and three-dimensional cell cultures are organized into distinct radial zones. Chromosome Res. 2011, 19, 165-182. [CrossRef]

217. Sexton, T.; Umlauf, D.; Kurukuti, S.; Fraser, P. The role of transcription factories in large-scale structure and dynamics of interphase chromatin. Semin. Cell Dev. Biol. 2007, 18, 691-697. [CrossRef]

218. Finlan, L.E.; Sproul, D.; Thomson, I.; Boyle, S.; Kerr, E.; Perry, P.; Ylstra, B.; Chubb, J.R.; Bickmore, W.A. Recruitment to the nuclear periphery can alter expression of genes in human cells. PLoS Genet. 2008, 4, e1000039. [CrossRef]

219. Falk, M.; Feodorova, Y.; Naumova, N.; Imakaev, M.; Lajoie, B.R.; Leonhardt, H.; Joffe, B.; Dekker, J.; Fudenberg, G.; Solovei, I.; et al. Heterochromatin drives compartmentalization of inverted and conventional nuclei. Nature 2019, 570, 395-399. [CrossRef] [PubMed]

220. Fishman, V.; Battulin, N.; Nuriddinov, M.; Maslova, A.; Zlotina, A.; Strunov, A.; Chervyakova, D.; Korablev, A.; Serov, O.; Krasikova, A. 3D organization of chicken genome demonstrates evolutionary conservation of topologically associated domains and highlights unique architecture of erythrocytes' chromatin. Nucleic Acids Res. 2019, 47, 648-665. [CrossRef]

221. Fontdevila, A. Genetic instability and rapid speciation: Are they coupled? Genetica 1992, 86, 247-258. [CrossRef]

222. Kazazian, J. L1 retrotransposons shape the mammalian genome. Science 2000, 289, 1152-1153. [CrossRef]

223. Kidwell, M.G.; Holyoake, A.J. Transposon-induced hotspots for genomic instability. Genome Res. 2001, 11, 1321-1322. [CrossRef]

224. Srikulnath, K.; Matsubara, K.; Uno, Y.; Thongpan, A.; Suputtitada, S.; Nishida-Umehara, C.; Matsuda, Y.; Apisitwanich, S. Genetic relationship of three butterfly lizard species (Leiolepis reevesii rubritaeniata, Leiolepis belliana belliana, Leiolepis boehmei, Agamidae, Squamata) inferred from nuclear gene sequence analyses. Kasetsart J. Nat. Sci. 2010, 44, 424-435.

225. Ahmad, S.F.; Singchat, W.; Jehangir, M.; Suntronpong, A.; Panthum, T.; Malaivijitnond, S.; Srikulnath, K. Dark matter of primate genomes: Satellite DNA repeats and their evolutionary dynamics. Cells 2020, 9, 2714. [CrossRef]

226. Fan, H.; Chu, J.Y. A brief review of short tandem repeat mutation. Genom. Proteom. Bioinform. 2007, 5, 7-14. [CrossRef]

227. Melters, D.P.; Bradnam, K.R.; Young, H.A.; Telis, N.; May, M.R.; Ruby, J.G.; Sebra, R.; Peluso, P.; Eid, J.; Rank, D.; et al. Comparative analysis of tandem repeats from hundreds of species reveals unique insights into centromere evolution. Genome Biol. 2013, 14, 1-20. [CrossRef] [PubMed]

228. Hartley, G.; O'neill, R.J. Centromere repeats: Hidden gems of the genome. Genes 2019, 10, 223. [CrossRef]

229. Nanda, I.; Schrama, D.; Feichtinger, W.; Haaf, T.; Schartl, M.; Schmid, M. Distribution of telomeric (TTAGGG) $\mathrm{n}$ sequences in avian chromosomes. Chromosoma 2002, 111, 215-227. [CrossRef] [PubMed]

230. Clemente, L.; Mazzoleni, S.; Bellavia, E.P.; Augstenová, B.; Auer, M.; Praschag, P.; Protiva, T.; Velenský, P.; Wagner, P.; Fritz, U.; et al. Interstitial telomeric repeats are rare in turtles. Genes 2020, 11, 657. [CrossRef] [PubMed]

231. Völker, M.; Backström, N.; Skinner, B.M.; Langley, E.J.; Bunzey, S.K.; Ellegren, H.; Griffin, D.K. Copy number variation, chromosome rearrangement, and their association with recombination during avian evolution. Genome Res. 2010, 20 , 503-511. [CrossRef]

232. Ashley, T.; Ward, D.C. A "hot-spot" of recombination coincides with an interstitial telomeric sequence in the Armenian hamster. Cytogenet. Cell Genet. 1993, 62, 169-171. [CrossRef]

233. Zakian, V.A.; Pluta, A.F. Telomere formation in yeast. Nature 1989, 338, 468. [CrossRef]

234. Matsubara, K.; Uno, Y.; Srikulnath, K.; Seki, R.; Nishida-Umehara, C.; Matsuda, Y. Molecular cloning and characterization of satellite DNA sequences from constitutive heterochromatin of the habu snake (Protobothrops flavoviridis, Viperidae) and the Burmese python (Python bivittatus, Pythonidae). Chromosoma 2015, 124, 529-539. [CrossRef]

235. Matsubara, K.; Tarui, H.; Toriba, M.; Yamada, K.; Nishida-Umehara, C.; Agata, K.; Matsuda, Y. Evidence for different origin of sex chromosomes in snakes, birds, and mammals and step-wise differentiation of snake sex chromosomes. Proc. Natl. Acad. Sci. USA 2006, 103, 18190-18195. [CrossRef] [PubMed]

236. Ezaz, T.; Deakin, J.E. Repetitive sequence and sex chromosome evolution in vertebrates. Adv. Evol. Biol. 2014, 2014, 1-9. [CrossRef]

237. Furman, B.L.S.; Metzger, D.C.H.; Darolti, I.; Wright, A.E.; Sandkam, B.A.; Almeida, P.; Shu, J.J.; Mank, J.E.; Fraser, B. Sex chromosome evolution: So many exceptions to the rules. Genome Biol. Evol. 2020, 12, 750-763. [CrossRef]

238. Garrido-Ramos, M.A. Satellite DNA: An evolving topic. Genes 2017, 8, 230. [CrossRef]

239. Miga, K.H. Centromeric satellite DNAs: Hidden sequence variation in the human population. Genes 2019, 10, 352. [CrossRef]

240. Weissensteiner, M.H.; Suh, A. Repetitive DNA: The dark matter of avian genomics. In Avian Genomics in Ecology and Evolution; Kraus, R., Ed.; Springer: Cham, Switzerland, 2019; pp. 93-150.

241. GBIF Secretariat. Colaptes melanochloros (Gmelin, 1788). GBIF Backbone Taxonomy. Available online: https://www.gbif.org/ species / 2478272 (accessed on 22 June 2021).

242. GBIF Secretariat. Colaptes campestris (Vieillot, 1818). GBIF Backbone Taxonomy. 2021. Available online: https://www.gbif.org/ $\mathrm{ru} /$ species / 2478233 (accessed on 22 June 2021).

243. de Oliveira, T.D.; Kretschmer, R.; Bertocchi, N.A.; Degrandi, T.M.; De Oliveira, E.H.C.; De Cioffi, M.B.; Garnero, A.D.V.; Gunski, R.J. Genomic organization of repetitive DNA in woodpeckers (Aves, Piciformes): Implications for karyotype and ZW sex chromosome differentiation. PLoS ONE 2017, 12, e169987. [CrossRef] 
244. Yamada, K.; Nishida-Umehara, C.; Matsuda, Y. Molecular and cytogenetic characterization of site-specific repetitive DNA sequences in the Chinese soft-shelled turtle (Pelodiscus sinensis, Trionychidae). Chromosome Res. 2005, 13, 33-46. [CrossRef] [PubMed]

245. Wagler, G. Natürliches System der Amphibien, mit Vorangehender Classification der Säugetiere und Vögel. Ein Beitrag zur Vergleichenden Zoologie. 1.0; JG Cotta: München/Stuttgart/Tübingen, Germany, 1830; p. 354.

246. Gray, J.E. Description of a new species of Staurotypus (S. salvinii) from Guatemala. Ann. Mag. Nat. Hist. 1864, 14, 451-452.

247. Kawagoshi, T.; Uno, Y.; Nishida-Umehara, C.; Matsuda, Y. The Staurotypus turtles and aves share the same origin of sex chromosomes but evolved different types of heterogametic sex determination. PLoS ONE 2014, 9, e105315. [CrossRef] [PubMed]

248. Thongchum, R.; Singchat, W.; Laopichienpong, N.; Tawichasri, P.; Kraichak, E.; Prakhongcheep, O.; Sillapaprayoon, S.; Muangmai, N.; Baicharoen, S.; Suntrarachun, S.; et al. Diversity of PBI-DdeI satellite DNA in snakes correlates with rapid independent evolution and different functional roles. Sci. Rep. 2019, 9, 1-11. [CrossRef]

249. Capriglione, T.; Cardone, A.; Odierna, G.; Olmo, E. Evolution of a centromeric satellite DNA and phylogeny of lacertid lizards. Comp. Biochem. Physiol. B Biochem. Mol. Biol. 1991, 100, 641-645. [CrossRef]

250. Capriglione, T.; Cardone, A.; Odierna, G.; Olmo, E. Further data on the occurrence and evolution of satellite DNA families in the lacertid genome. Chromosome Res. 1994, 2, 327-330. [CrossRef]

251. Capriglione, T.; De Santo, M.G.; Odierna, G.; Olmo, E. An alphoid-like satellite DNA sequence is present in the genome of a lacertid lizard. J. Mol. Evol. 1998, 46, 240-244. [CrossRef]

252. Ciobanu, D.; Grechko, V.V.; Darevsky, I.S.; Kramerov, D.A. New satellite DNA in Lacerta s. str. lizards (Sauria: Lacertidae): Evolutionary pathways and phylogenetic impact. J. Exp. Zool. Part B 2004, 302, 505-516. [CrossRef] [PubMed]

253. Grechko, V.V.; Ciobanu, D.G.; Darevsky, I.S.; Kramerov, D.A. Satellite DNA of lizards of the genus Lacerta s. str. (the Group L. agilis), the family Lacertidae. Dokl. Biochem. Biophys. 2005, 400, 44-47. [CrossRef] [PubMed]

254. Giovannotti, M.; S’Khifa, A.; Nisi Cerioni, P.; Splendiani, A.; Slimani, T.; Fioravanti, T.; Olmo, E.; Caputo Barucchi, V. Isolation and characterization of two satellite DNAs in Atlantolacerta andreanskyi (Werner, 1929) (Reptilia, Lacertidae). J. Exp. Zool. Part B 2020, 334, 178-191. [CrossRef]

255. Giovannotti, M.; Cerioni, P.N.; Caputo, V.; Olmo, E. Characterisation of a GC-rich telomeric satellite DNA in Eumeces schneideri Daudin (Reptilia, Scincidae). Cytogenet. Genome Res. 2009, 125, 272-278. [CrossRef]

256. Giovannotti, M.; Cerioni, P.N.; Splendiani, A.; Ruggeri, P.; Olmo, E.; Barucchi, V.C. Slow evolving satellite DNAs: The case of a centromeric satellite in Chalcides ocellatus (Forskål, 1775) (Reptilia, Scincidae). Amphib. Reptil. 2013, 34, 401-411. [CrossRef]

257. Matsubara, K.; Sarre, S.D.; Georges, A.; Matsuda, Y.; Graves, J.A.M.; Ezaz, T. Highly differentiated ZW sex microchromosomes in the Australian varanus species evolved through rapid amplification of repetitive sequences. PLoS ONE 2014, 9, e95226. [CrossRef] [PubMed]

258. Prakhongcheep, O.; Thapana, W.; Suntronpong, A.; Singchat, W.; Pattanatanang, K.; Phatcharakullawarawat, R.; Muangmai, N.; Peyachoknagul, S.; Matsubara, K.; Ezaz, T.; et al. Lack of satellite DNA species-specific homogenization and relationship to chromosomal rearrangements in monitor lizards (Varanidae, Squamata). BMC Evol. Biol. 2017, 17, 193. [CrossRef]

259. Plohl, M.; Meštrović, N.; Mravinac, B. Satellite DNA evolution. In Repetitive DNA; Garrido-Ramos, M.A., Ed.; Karger: Basel, Switzerland, 2012; Volume 7, pp. 126-152. [CrossRef]

260. Werner, F. Wissenschaftliche Ergebnisse einer zoologischen Forschungsreise nach Westalgerien und Marokko. In Sitzungsberichte der Akademie der Wissenschaften Mathematisch-Naturwissenschaftliche Klasse; Verlag der Österreichischen Akademie der Wissenschaften: Vienna, Austria, 1929; Volume 138, pp. 1-34.

261. Deraniyagala, P.E.P. Four new races of the "Kabaragoya" lizard Varanus salvator. Spolia Zeylan. 1944, $24,59-62$.

262. Chaiprasertsri, N.; Uno, Y.; Peyachoknagul, S.; Prakhongcheep, O.; Baicharoen, S.; Charernsuk, S.; Nishida-Umehara, C.; Matsuda, Y.; Koga, A.; Srikulnath, K. Highly species-specific centromeric repetitive DNA sequences in lizards: Molecular cytogenetic characterization of a novel family of satellite DNA sequences isolated from the water monitor lizard (Varanus salvator macromaculatus, Platynota). J. Hered. 2013, 104, 798-806. [CrossRef]

263. Hallowell, E. Report upon the Reptilia of the North Pacific Exploring Expedition, under command of Capt. John Rogers, U.S.N. Proc. Acad. Nat. Sci. USA 1861, 12, 480-510.

264. Kuhl, H. Beiträge zur Zoologie und Vergleichenden Anatomie; Hermannsche Buchhandlung: Frankfurt, Germany, $1820 ;$ p. 152.

265. Schneider, J.G. Historiae Amphibiorum Naturalis et Literariae. Fasciculus Secundus Continens Crocodilos. Scincos. Chamaesauras, Boas. Pseudoboas, Elapes, Angues. Amphisbaenas et Caecilias; Frommanni: Jena, Germany, 1801; p. 374.

266. Tiersch, T.R.; Wachtel, S.S. On the evolution of genome size of birds. J. Hered. 1991, 82, 363-368. [CrossRef]

267. Holmquist, G.P. Evolution of chromosome bands: Molecular ecology of noncoding DNA. J. Mol. Evol. 1989, $28,469-486$. [CrossRef]

268. Vandergon, T.L.; Reitman, M. Evolution of chicken repeat 1 (CR1) elements: Evidence for ancient subfamilies and multiple progenitors. Mol. Biol. Evol. 1994, 11, 886-898. [CrossRef] [PubMed]

269. Chowdhary, B.P.; Raudsepp, T.; Frönicke, L.; Scherthan, H. Emerging patterns of comparative genome organization in some mammalian species as revealed by Zoo-FISH. Genome Res. 1998, 8, 577-589. [CrossRef] [PubMed]

270. Takagi, N.; Sasaki, M. A phylogenetic study of bird karyotypes. Chromosoma 1974, 46, 91-120. [CrossRef] [PubMed]

271. Belterman, R.H.R.; De Boer, L.E.M. A miscellaneous collection of bird karyotypes. Genetica 1990, 83, 17-29. [CrossRef] 
272. Jones, C.T.; Morrice, D.R.; Paton, I.R.; Burt, D.W. Homologues of genes on human chromosome $15 \mathrm{q} 21 \rightarrow \mathrm{q} 26$ and a chicken microchromosome show conserved synteny and gene order. Mamm. Genome 1997, 8, 436-440. [CrossRef]

273. Masabanda, J.; Friedl, R.; Sazanov, A.; Lahti, J.M.; Li, H.; Kidd, V.J.; Fries, R. Mapping of five members of the cyclin gene family on chicken chromosomes by FISH. Chromosome Res. 1998, 6, 231-232. [CrossRef] [PubMed]

274. Sazanov, A.; Masabanda, J.; Ewald, D.; Takeuchi, S.; Tixier-Boichard, M.; Buitkamp, J.; Fries, R. Evolutionarily conserved telomeric location of $B B C 1$ and MC1Ron a microchromosome questions the identity of MC1Rand a pigmentation locus on chromosome 1 in chicken. Chromosome Res. 1998, 6, 651-654. [CrossRef] [PubMed]

275. De Lucca, E. Karyotype and nucleolus organizing regions in somatic chromosomes of the white-tailed hawk Buteo albicaudatus (Falconiformes: Aves). Cytobios 1985, 42, 7-13.

276. Modesto, S.P.; Anderson, J.S. The phylogenetic definition of reptilia. Syst. Biol. 2004, 53, 815-821. [CrossRef] [PubMed]

277. Wiens, J.J. Systematics and herpetology in the age of genomics. Bioscience 2008, 58, 297-307. [CrossRef]

278. Painter, T.S. The Y-chromosome in mammals. Science 1921, 53, 503-504. [CrossRef]

279. Matthey, R.; Rovey, R. The chromosome formula in five species of Chiroptera. Cell. Mol. Life Sci. 1948, 4, 26.

280. Peccinini, D.; Frota-Pessoa, O.; Ferrari, I. Sex determination of the "pseudo-xo/xx" type in the Brazilian lizard Polychrus sp. (Sauria, Iguanidae). Caryologia 1971, 24, 129-139. [CrossRef]

281. Matsubara, K.; O’Meally, D.; Sarre, S.D.; Georges, A.; Srikulnath, K.; Ezaz, T. ZW sex chromosomes in Australian dragon lizards (Agamidae) originated from a combination of duplication and translocation in the nucleolar organising region. Genes 2019, 10, 861. [CrossRef]

282. Schoepff, J.D. Historia Testudinum Iconibus Illustrata; Palm, J.J., Ed.; Harvard University: Cambridge, MA, USA, 1972; Volume xii, pp. 1-32.

283. Kasai, F.; O'Brien, P.C.M.; Ferguson-Smith, M.A. Reassessment of genome size in turtle and crocodile based on chromosome measurement by flow karyotyping: Close similarity to chicken. Biol. Lett. 2012, 8, 631-635. [CrossRef] [PubMed]

284. Shedlock, A.M.; Edwards, S.V. Amniotes (Amniota). In The Timetree of Life; Hedges, S.B., Kumar, S., Eds.; Oxford University Press: New York, NY, USA, 2009; pp. 375-379.

285. Pokorná, M.J.; Rovatsos, M.; Kratochvíl, L. Sex chromosomes and karyotype of the (nearly) mythical creature, the Gila monster, Heloderma suspectum (Squamata: Helodermatidae). PLoS ONE 2014, 9, e104716. [CrossRef]

286. Damas, J.; O'Connor, R.; Farré, M.; Lenis, V.P.E.; Martell, H.J.; Mandawala, A.; Fowler, K.; Joseph, S.; Swain, M.T.; Griffin, D.K.; et al. Upgrading short-read animal genome assemblies to chromosome level using comparative genomics and a universal probe set. Genome Res. 2017, 27, 875-884. [CrossRef]

287. O'Connor, R.E.; Farré, M.; Joseph, S.; Damas, J.; Kiazim, L.; Jennings, R.; Bennett, S.; Slack, E.A.; Allanson, E.; Larkin, D.M.; et al. Chromosome-level assembly reveals extensive rearrangement in saker falcon and budgerigar, but not ostrich, genomes. Genome Biol. 2018, 19, 1-15. [CrossRef] [PubMed]

288. Sun, X.; Huang, L.; Markowitz, T.E.; Blitzblau, H.G.; Chen, D.; Klein, F.; Hochwagen, A. Transcription dynamically patterns the meiotic chromosome-axis interface. eLife 2015, 4, e07424. [CrossRef] [PubMed]

289. Potter, I.C.; Rothwell, B. The mitotic chromosomes of the lamprey, Petromyzon marinus L. Experientia 1970, 26, 429-430. [CrossRef]

290. Smith, J.J.; Stuart, A.B.; Sauka-Spengler, T.; Clifton, S.W.; Amemiya, C.T. Development and analysis of a germline BAC resource for the sea lamprey, a vertebrate that undergoes substantial chromatin diminution. Chromosoma 2010, 119, 381-389. [CrossRef]

291. Covelo-Soto, L.; Morán, P.; Pasantes, J.J.; Pérez-García, C. Cytogenetic evidences of genome rearrangement and differential epigenetic chromatin modification in the sea lamprey (Petromyzon marinus). Genetica 2014, 142, 545-554. [CrossRef]

292. Smith, J.J.; Timoshevskaya, N.; Ye, C.; Holt, C.; Keinath, M.C.; Parker, H.J.; Cook, M.E.; Hess, J.E.; Narum, S.R.; Lamanna, F.; et al. The sea lamprey germline genome provides insights into programmed genome rearrangement and vertebrate evolution. Nat. Genet. 2018, 50, 270-277. [CrossRef]

293. Mehta, T.K.; Raèi, Ė.; Yamasaki, S.; Lee, A.P.; Lian, M.M.; Tay, B.H.; Tohari, S.; Yanai, S.; Tay, A.; Brenner, S.; et al. Evidence for at least six Hox clusters in the Japanese lamprey (Lethenteron japonicum). Proc. Natl. Acad. Sci. USA 2013, 110, 16044-16049. [CrossRef]

294. O'Connor, R.E.; Romanov, M.N.; Kiazim, L.G.; Barrett, P.M.; Farré, M.; Damas, J.; Ferguson-Smith, M.; Valenzuela, N.; Larkin, D.M.; Griffin, D.K. Reconstruction of the diapsid ancestral genome permits chromosome evolution tracing in avian and non-avian dinosaurs. Nat. Commun. 2018, 9, 1-9. [CrossRef] [PubMed]

295. Blair Hedges, S.; Poling, L.L. A molecular phylogeny of reptiles. Science 1999, 283, 998-1001. [CrossRef] [PubMed]

296. Benton, M.J. Phylogeny of the major tetrapod groups: Morphological data and divergence dates. J. Mol. Evol. 1990, 30, 409-424. [CrossRef] [PubMed]

297. Romanov, M.N.; Farré, M.; Lithgow, P.E.; Fowler, K.E.; Skinner, B.M.; O’Connor, R.; Fonseka, G.; Backström, N.; Matsuda, Y.; Nishida-Umehara, C.; et al. Reconstruction of gross avian genome structure, organization and evolution suggests that the chicken lineage most closely resembles the dinosaur avian ancestor. BMC Genom. 2014, 15, 1060. [CrossRef] [PubMed]

298. Nishida-Umehara, C.; Tsuda, Y.; Ishijima, J.; Ando, J.; Fujiwara, A.; Matsuda, Y.; Griffin, D.K. The molecular basis of chromosome orthologies and sex chromosomal differentiation in palaeognathous birds. Chromosome Res. 2007, 15, 721-734. [CrossRef]

299. Nanda, I.; Karl, E.; Griffin, D.K.; Schartl, M.; Schmid, M. Chromosome repatterning in three representative parrots (Psittaciformes) inferred from comparative chromosome painting. Cytogenet. Genome Res. 2007, 117, 43-53. [CrossRef] [PubMed] 
300. Cooper, A.; Penny, D. Mass survival of birds across the Cretaceous-tertiary boundary: Molecular evidence. Science 1997, 275, 1109-1113. [CrossRef] [PubMed]

301. Burt, D.W. Chromosome rearrangement in evolution. In Encyclopedia of Life Sciences; Nature Publishing Group, MacMillan Publishers: London, UK, 2001. [CrossRef]

302. Kearney, M.; Hewitt, G. Stasipatric speciation: Resurrecting a system to bury a hypothesis? Mol. Ecol. 2009, 18, 3331-3333. [CrossRef]

303. Bush, G.L.; Case, S.M.; Wilson, A.C.; Patton, J.L. Rapid speciation and chromosomal evolution in mammals. Proc. Natl. Acad. Sci. USA 1977, 74, 3942-3946. [CrossRef]

304. Szarski, H. Cell size and the concept of wasteful and frugal evolutionary strategies. J. Theor. Biol. 1983, 21, 201-209. [CrossRef]

305. Castoe, T.A.; De Koning, A.P.J.; Hall, K.T.; Card, D.C.; Schield, D.R.; Fujita, M.K.; Ruggiero, R.P.; Degner, J.F.; Daza, J.M.; Gu, W.; et al. The Burmese python genome reveals the molecular basis for extreme adaptation in snakes. Proc. Natl. Acad. Sci. USA 2013, 110, 20645-20650. [CrossRef] [PubMed]

306. Ouwens, P.A. On a large Varanus species from the island of Komodo. Bull. Jard. Bot. Buitenzorg 1912, 6, 1-3.

307. Lind, A.L.; Lai, Y.Y.Y.; Mostovoy, Y.; Holloway, A.K.; Iannucci, A.; Mak, A.C.Y.; Fondi, M.; Orlandini, V.; Eckalbar, W.L.; Milan, M.; et al. Genome of the Komodo dragon reveals adaptations in the cardiovascular and chemosensory systems of monitor lizards. Nat. Ecol. Evol. 2019, 3, 1241-1252. [CrossRef] [PubMed]

308. Cohen, M.M.; Gans, C. The chromosomes of the order Crocodilia. Cytogenet. Genome Res. 1970, 9, 81-105. [CrossRef]

309. De Boer, L.E.M.; Sinoo, R.P. A karyological study of Accipitridae (Aves: Falconiformes), with karyotypic descriptions of 16 species new to cytology. Genetica 1984, 65, 89-107. [CrossRef]

310. Alberts, B.; Johnson, A.; Lewis, J.; Raff, M.; Roberts, K.; Walter, P. Molecular Biology of the Cell: How Genomes Evolve, 4th ed.; Garland Science: New York, NY, USA, 2002. Available online: https:/ /www.ncbi.nlm.nih.gov/books/NBK26836/ (accessed on 22 June 2021).

311. Waddington, D.; Springbett, A.J.; Burt, D.W. A chromosome-based model for estimating the number of conserved segments between pairs of species from comparative genetic maps. Genetics 2000, 154, 323-332. [CrossRef]

312. Stapley, J.; Feulner, P.G.D.; Johnston, S.E.; Santure, A.W.; Smadja, C.M. Variation in recombination frequency and distribution across eukaryotes: Patterns and processes. Philos. Trans. R. Soc. B Biol. Sci. 2017, 372, 20160455. [CrossRef]

313. Coyne, J.A.; Orr, H.A. Speciation; Sinauer Associates: Sunderland, MA, USA, 2004.

314. Butlin, R.K. Recombination and speciation. Mol. Ecol. 2005, 14, 2621-2635. [CrossRef] [PubMed]

315. Ortiz-Barrientos, D.; Engelstädter, J.; Rieseberg, L.H. Recombination rate evolution and the originof species. Trends Ecol. Evol. 2016, 31, 226-236. [CrossRef]

316. Payseur, B.A.; Rieseberg, L.H. A genomic perspective on hybridization and speciation. Mol. Ecol. 2016, 25, 2337-2360. [CrossRef] [PubMed]

317. Toews, D.P.; Taylor, S.A.; Vallender, R.; Brelsford, A.; Butcher, B.G.; Messer, P.W.; Lovette, I.J. Plumage genes and little else distinguish the genomes of Hybridizing Warblers. Curr. Biol. 2016, 26, 2313-2318. [CrossRef] [PubMed]

318. Campagna, L.; Repenning, M.; Silveira, L.F.; Fontana, C.S.; Tubaro, P.L.; Lovette, I.J. Repeated divergent selection on pigmentation genes in a rapid finch radiation. Sci. Adv. 2017, 3, e1602404. [CrossRef] [PubMed]

319. Poelstra, J.W.; Vijay, N.; Bossu, C.M.; Lantz, H.; Ryll, B.; Müller, I.; Baglione, V.; Unneberg, P.; Wikelski, M.; Grabherr, M.G.; et al. The genomic landscape underlying phenotypic integrity in the face of gene flow in crows. Science 2014, 344, 1410-1414. [CrossRef] [PubMed]

320. Stryjewski, K.F.; Sorenson, M.D. Mosaic genome evolution in a recent and rapid avian radiation. Nat. Ecol. Evol. 2017, 1, 1912-1922. [CrossRef]

321. Yin, W.; Wang, Z.J.; Li, Q.Y.; Lian, J.M.; Zhou, Y.; Lu, B.Z.; Jin, L.J.; Qiu, P.X.; Zhang, P.; Zhu, W.B.; et al. Evolutionary trajectories of snake genes and genomes revealed by comparative analyses of five-pacer viper. Nat. Commun. 2016, 7, 13107. [CrossRef] [PubMed]

322. Wolf, J.B.; Ellegren, H. Making sense of genomic islands of differentiation in light of speciation. Nat. Rev. Genet. 2017, 18, 87-100. [CrossRef]

323. Campbell, C.R.; Poelstra, J.W.; Yoder, A.D. What is speciation genomics? The roles of ecology, gene flow, and genomic architecture in the formation of species. Biol. J. Linn. Soc. 2018, 124, 561-583. [CrossRef]

324. Muller, H.J. The relation of recombination to mutational advance. Mutat. Res. Fundam. Mol. Mech. Mutagenesis 1964, 1, 2-9. [CrossRef]

325. Kondrashov, A.S. Deleterious mutations and the evolution of sexual reproduction. Nature 1988, 336, 435-441. [CrossRef]

326. Haddrill, P.R.; Halligan, D.L.; Tomaras, D.; Charlesworth, B. Reduced efficacy of selection in regions of the Drosophila genome that lack crossing over. Genome Biol. 2007, 8, 1-9. [CrossRef]

327. Hill, W.G.; Robertson, A. The effect of linkage on limits to artificial selection. Genet. Res. 2007, 89, 311-336. [CrossRef] [PubMed]

328. Dumont, B.L.; Payseur, B.A. Evolution of the genomic rate of recombination in mammals. Evolution 2008, 62, 276-294. [CrossRef] [PubMed]

329. Martin, S. Global diversity of crocodiles (Crocodilia, Reptilia) in freshwater. In Freshwater Animal Diversity Assessment; Springer: Dordrecht, The Netherlands, 2007; Volume 198, pp. 587-591. 
330. Dawson, D.A.; Åkesson, M.; Burke, T.; Pemberton, J.M.; Slate, J.; Hansson, B. Gene order and recombination rate in homologous chromosome regions of the chicken and a passerine bird. Mol. Biol. Evol. 2007, 24, 1537-1552. [CrossRef] [PubMed]

331. Duret, L.; Mouchiroud, D.; Gautier, C. Statistical analysis of vertebrate sequences reveals that long genes are scarce in GC-rich isochores. J. Mol. Evol. 1995, 40, 308-317. [CrossRef]

332. Likhoshvai, V.A.; Matushkin, Y.G. Nucleotide composition-based prediction of gene expression efficacy. Mol. Biol. 2000, 34, 345-350. [CrossRef]

333. Elhaik, E.; Pellegrini, M.; Tatarinova, T.V. Gene expression and nucleotide composition are associated with genic methylation level in Oryza sativa. BMC Bioinform. 2014, 15, 23. [CrossRef]

334. Halder, B.; Malakar, A.K.; Chakraborty, S. Nucleotide composition determines the role of translational efficiency in human genes. Bioinformation 2017, 13, 46-53. [CrossRef]

335. Choudhury, M.N.; Uddin, A.; Chakraborty, S. Gene expression, nucleotide composition and codon usage bias of genes associated with human Y chromosome. Genetica 2017, 145, 295-305. [CrossRef]

336. Zahdeh, F.; Carmel, L. Nucleotide composition affects codon usage toward the $3^{\prime}$-end. PLoS ONE 2019, 14, e0225633. [CrossRef]

337. Zrimec, J.; Börlin, C.S.; Buric, F.; Muhammad, A.S.; Chen, R.; Siewers, V.; Verendel, V.; Nielsen, J.; Töpel, M.; Zelezniak, A. Deep learning suggests that gene expression is encoded in all parts of a co-evolving interacting gene regulatory structure. Nat. Commun. 2020, 11, 1-16. [CrossRef]

338. Nordborg, M.; Charlesworth, B.; Charlesworth, D. The effect of recombination on background selection. Genet. Res. 1996, 67, 159-174. [CrossRef] [PubMed] 